\title{
Article \\ Heterocornols from the Sponge-Derived Fungus Pestalotiopsis heterocornis with Anti-Inflammatory Activity
}

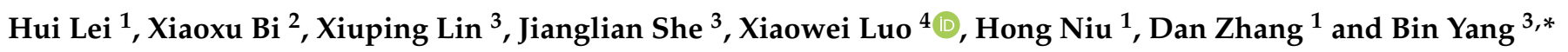 \\ 1 School of Pharmacy, Southwest Medical University, Luzhou 646000, China; huilei@swmu.edu.cn (H.L.); \\ dawn123454@swmu.edu.cn (H.N.); zhangdan@swmu.edu.cn (D.Z.) \\ 2 College of Agriculture and Life Sciences, Kunming University, Kunming 650241, China; bxx2797@163.com \\ 3 CAS Key Laboratory of Tropical Marine Bio-Resources and Ecology, Guangdong Key Laboratory of Marine \\ Materia Medica, South China Sea Institute of Oceanology, Chinese Academy of Sciences, \\ Guangzhou 510301, China; xiupinglin@scsio.ac.cn (X.L.); shejianglian20@mails.ucas.ac.cn (J.S.) \\ 4 Institute of Marine Drugs, Guangxi University of Chinese Medicine, Nanning 530200, China; \\ luoxw@gxtcmu.edu.cn \\ * Correspondence: yangbin@scsio.ac.cn; Tel.: +86-020-89023174
}

Citation: Lei, H.; Bi, X.; Lin, X.; She, J.; Luo, X.; Niu, H.; Zhang, D.; Yang, B. Heterocornols from the Sponge-Derived Fungus Pestalotiopsis heterocornis with Anti-Inflammatory Activity. Mar. Drugs 2021, 19, 585. https://doi.org/10.3390/md19110585

Academic Editors: Bill J. Baker and Micha Ilan

Received: 23 August 2021

Accepted: 15 October 2021

Published: 20 October 2021

Publisher's Note: MDPI stays neutral with regard to jurisdictional claims in published maps and institutional affiliations.

Copyright: (c) 2021 by the authors. Licensee MDPI, Basel, Switzerland. This article is an open access article distributed under the terms and conditions of the Creative Commons Attribution (CC BY) license (https:/ / creativecommons.org/licenses/by/ $4.0 /)$.

\begin{abstract}
One strain-many compounds (OSMAC) manipulation of the sponge-derived fungus Pestalotiopsis heterocornis XWS03F09 resulted in the production of new secondary metabolites. The chemical study of the fermentation, cultivated on $3 \%$ artificial sea salt in the rice media, led to the isolation of twelve compounds, including eight new polyketide derivatives, heterocornols Q$X(1-8)$, one new ceramide (9), and three known analogues (10-12). The structures and absolute configurations of the new compounds were elucidated by spectroscopic data and calculated ECD analysis. Heterocornols Q (1) and R (2) are novel 6/5/7/5 tetracyclic polyketide derivatives featuring dihydroisobenzofuran and benzo-fused dioxabicyclo [4.2.1] nonane system, which might be derived from the acetyl-CoA by epoxidation, polyene cyclization, and rearrangement to form the core skeleton. Compound 12 showed moderate or weak antimicrobial activities against with MIC values ranging from 25 to $100 \mu \mathrm{g} / \mathrm{mL}$. Heterocornols T and X (7 and 8) could inhibit the production of LPS-induced NO significantly, comparable to dexamethasone. Further Western blotting analysis showed 7 and 8 markedly suppressed the iNOS protein expression in LPS-induced RAW 264.7 cells in a dosedependent manner. The result showed that $\mathbf{7}$ and $\mathbf{8}$ might serve as potential leads for development of anti-inflammatory activity.
\end{abstract}

Keywords: Pestalotiopsis heterocornis; heterocornols; anti-inflammatory activity; sponge-derived fungus

\section{Introduction}

During the past several decades, marine-derived fungi are recognized as an important source of novel drug leads. However, most of their biosynthetic gene clusters are silent under laboratory conditions fungi, whereas only a fraction of gene clusters have been transcribed. In order to enlarge the diversity of metabolites, different strategies such as the one strain-many compounds (OSMAC) strategy [1-5], epigenetic modification [6-8], and genome mining have been devoted to activating the silent gene clusters [9-13]. Among them, the OSMAC strategy represents a simple strategy involving the systematic alteration of culture conditions.

Our previous investigation on the marine sponge-derived fungus Pestalotiopsis heterocornis XWS03F09 has resulted in the discovery of heterocornols A-P [14,15], pestaloisocoumarins A and B, isopolisin B, and pestalotiol A [16]. For exploring the chemical diversity of microorganisms using the OSMAC strategy, we reinvestigated the secondary metabolites of the strain XWS03F09, with additional 3\% artificial sea salt to solid rice medium. Further chemical exploration resulted in the isolation of eight new polyketide derivatives, heterocornols Q-X (1-8), and one new ceramide (9), together with three known analogues, 
pestalone (10) [17], and pestalachlorides A and B (11 and 12) [18]. The isolated compounds (1-9 and 12) were evaluated for the cytotoxic, antimicrobial, and anti-inflammatory activities in vitro. Here, we report the details of the isolation, structure elucidation, and biological activities of these compounds.

\section{Results and Discussion}

The fermentation of the fungus $P$. heterocornis XWS03F09 in the rice media was cultivated for 36 days, made up separately with different culture conditions $(0,1 \%, 3 \%, 5 \%$ artificial sea salt to solid rice medium), and then was extracted with EtOAc three times. The resulting extracts were analyzed by HPLC. The HPLC-UV profiles of the secondary metabolites indicated that they possessed almost the same metabolites, but with dramatical differences in their major constituents (Figure S56). As the concentration of artificial sea salt in the rice media increased, the strain stopped the production of some metabolites. The strain produced some new metabolites with 3\% salinity compared with the previous fermentation. The chemical study of the fermentation, cultivated on $3 \%$ artificial sea salt in the rice media, yielded twelve metabolites, including eight new polyketide derivatives, heterocornols Q-X (1-8), and one new ceramide (9) (Figure 1).

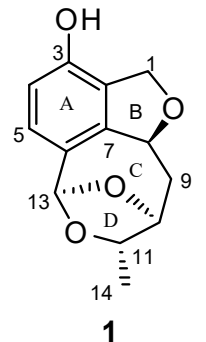<smiles>[Z]C1O[C@@H]2O[C@@H]1C[C@@H]1OCc3c(O)ccc1c32</smiles><smiles>CCOCc1c(O)ccc2c1[C@H](CC(=O)[C@H](C)OC(C)=O)C(C(C)(C)O)C2</smiles>

3<smiles>CCOCc1c(O)ccc2c1[C@H]1CC(C)(O)[C@@H](CC(=O)C(C)OC(C)=O)C21</smiles>

4

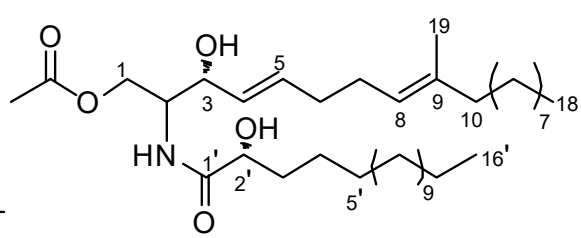

9<smiles>[R20]OC(C)[C@H](C)[C@H]1OCc2c(O)cccc21</smiles>

$5 \mathrm{R}_{1}=\mathrm{COCH}_{3}, \mathrm{R}_{2}=\mathrm{H}$ $6 \mathrm{R}_{1}=\mathrm{H}, \mathrm{R}_{2}=\mathrm{COCH}_{3}$

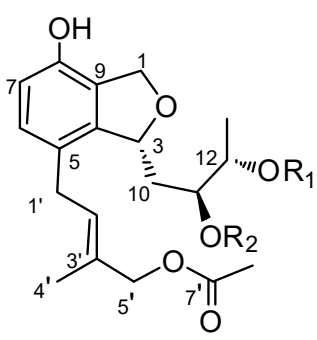

$7 \mathrm{R}_{1}=\mathrm{H}, \mathrm{R}_{2}=\mathrm{COCH}_{3}$ $8 \mathrm{R}_{1}=\mathrm{COCH}_{3}, \mathrm{R}_{2}=\mathrm{H}$<smiles>COc1c(Cl)c(C)c(Cl)c(O)c1[C@H]1c2c(O)cc(O)c3c2[C@@H](C=O)[C@H](C(C)(C)O)[C@H]31</smiles>

10<smiles>CC(C)=CCc1c(O)cc(O)c(C=O)c1C(=O)c1c(O)c(Cl)c(C)c(Cl)c1O</smiles>

11<smiles>COc1c(Cl)c(C)c(Cl)c(O)c1[C@H]1NC(=O)c2c(O)cc(O)c(CC=C(C)C)c21</smiles>

12

Figure 1. Structures of compounds 1-12.

Compound 1 was isolated as a white amorphous solid, and its molecular formula was established as $\mathrm{C}_{13} \mathrm{H}_{14} \mathrm{O}_{4}$ on the basis of HRESIMS at $m / z 257.0783[\mathrm{M}+\mathrm{Na}]^{+}$(Figure S1). The ${ }^{1} \mathrm{H}$ NMR spectrum (Table 1 and Figure S2) of $\mathbf{1}$ displayed resonances attributed to two aromatic protons at $\delta_{\mathrm{H}} 7.01(\mathrm{~d}, J=7.9 \mathrm{~Hz})$, and $6.58(\mathrm{~d}, J=7.9 \mathrm{~Hz})$ belonging to a 1,2,3,4tetrasubstituted benzene, one methyl $\left[\delta_{\mathrm{H}} 1.30(\mathrm{~d}, J=6.2 \mathrm{~Hz})\right.$, one dioxygenated methine $\left(\delta_{\mathrm{H}} 5.96, \mathrm{~s}\right)$, three oxygenated methines $\left[\delta_{\mathrm{H}} 5.50(\mathrm{dd}, J=8.3,2.5 \mathrm{~Hz}), 4.34(\mathrm{t}, J=2.5 \mathrm{~Hz})\right.$, and $\left.\delta_{\mathrm{H}} 4.61(\mathrm{q}, J=6.0 \mathrm{~Hz})\right]$, one oxygenated methylene $\left[\delta_{\mathrm{H}} 5.12(\mathrm{dd}, J=12.1,2.5 \mathrm{~Hz})\right.$, $4.96(\mathrm{dd}, J=12.1,2.7 \mathrm{~Hz})]$, one methylene $\left[\delta_{\mathrm{H}} 2.32(\mathrm{dt}, J=13.5,4.7 \mathrm{~Hz})\right.$, and $1.94(\mathrm{ddd}$, $J=13.5,11.3,2.8 \mathrm{~Hz}$ )]. The ${ }^{13} \mathrm{C}$ NMR and DEPT spectra (Figures S3 and S4) of 1 displayed 13 carbon signals corresponding to one methyl, two methylenes, six methines including two olefinic carbons, four oxygenated carbons, and four quaternary carbons. The NMR features of $\mathbf{1}$ were very similar to those of vaccinol P [19], indicating that 1 was a polyketide derivative structurally related to vaccinol $\mathrm{P}$. The major difference was the presence of an eight-membered carbon ring in 1, instead of the C-8 a side chain in vaccinol $\mathrm{P}$, which was supported by the additional HMBC correlations from H-13 $\left(\delta_{\mathrm{H}} 5.96\right)$ to $\mathrm{C}-11\left(\delta_{\mathrm{C}} 81.4\right)$, $\mathrm{C}-10\left(\delta_{\mathrm{C}} 77.3\right), \mathrm{C}-5\left(\delta_{\mathrm{C}} 127.1\right), \mathrm{C}-6\left(\delta_{\mathrm{C}} 129.4\right)$, and C-7 $\left(\delta_{\mathrm{C}} 143.7\right)$, from H-11 $\left(\delta_{\mathrm{H}} 4.34\right)$ to 
C-13 $\left(\delta_{\mathrm{C}} 106.4\right), \mathrm{C}-14\left(\delta_{\mathrm{C}} 21.1\right)$, together with the COSY correlations $\mathrm{H}-8 / \mathrm{H}-9 / \mathrm{H}-10 / \mathrm{H}-$ $11 / \mathrm{H}-14$ (Figure 2, Figures S5 and S6 ). Furthermore, the HMBC correlations between $\mathrm{H}-1\left(\delta_{\mathrm{H}} 4.96 / 5.12\right)$ and C-3 $\left(\delta_{\mathrm{C}} 153.4\right), \mathrm{C}-7\left(\delta_{\mathrm{C}} 143.7\right), \mathrm{C}-8\left(\delta_{\mathrm{C}} 82.6\right)$, and C-2 $\left(\delta_{\mathrm{C}} 127.4\right)$ indicated that a five-membered carbon ring was fused with ring $\mathrm{B}$ through $\mathrm{C}-2$ and $\mathrm{C}-7$. The HMBC correlations from $\mathrm{H}-11\left(\delta_{\mathrm{H}} 4.34\right)$ to $\mathrm{C}-13\left(\delta_{\mathrm{C}} 106.4\right), \mathrm{C}-14\left(\delta_{\mathrm{C}} 21.1\right)$, from H-9 $\left(\delta_{\mathrm{H}} 2.32 / 1.94\right)$ to $\mathrm{C}-7\left(\delta_{\mathrm{C}} 143.7\right), \mathrm{C}-8\left(\delta_{\mathrm{C}} 82.6\right)$, and C-10 $\left(\delta_{\mathrm{C}} 77.3\right)$ indicated that the C-11 of the vicinal diol side chain was connected with $\mathrm{C}-13$ through an O-bridged hemiketal moiety to form an eight-membered ring, which fused to both rings $\mathrm{A}$ and $\mathrm{B}$ sharing the same joined carbon C-7 and established a tricyclic $6 / 5 / 8$ skeleton. Benzene ring A, fivemembered ring $B$, and eight-membered ring accounted for six degrees of unsaturation, and the remaining ones thus required $\mathbf{1}$ to be tetracyclic. Furthermore, the HMBC correlations between $\mathrm{H}-10\left(\delta_{\mathrm{H}} 4.61\right)$ and C-13 $\left(\delta_{\mathrm{C}} 106.4\right), \mathrm{C}-8\left(\delta_{\mathrm{C}} 82.6\right)$. The different chemical shifts of $\mathrm{C}-10\left(\delta_{\mathrm{C}} 77.3\right), \mathrm{C}-11\left(\delta_{\mathrm{C}} 81.4\right)$, and $\mathrm{C}-13\left(\delta_{\mathrm{C}} 106.4\right)$ indicated that the eight-membered carbon ring was divided into rings $C$ and $D$. Therefore, 1 was identified to be a $6 / 5 / 7 / 5$ tetracyclic polyketide derivative featuring a novel carbon skeleton with a dihydroisobenzofuran and benzo-fused dioxabicyclo [4.2.1] nonane system. The relative configuration of $\mathbf{1}$ was determined by analyzing the NOESY correlations (Figure 3, Figure S7 ). The NOESY spectrum of 1 revealed cross-peaks from $\mathrm{H}-8$ to $\mathrm{H}-11$ and from $\mathrm{H}-10$ to $\mathrm{H}_{3}-14$, which, together with the lack of a correlation from $\mathrm{H}-10$ to $\mathrm{H}-11$, led to the determination of the relative configuration of $\mathbf{1}$ as $8 S, 10 S, 11 S, 13 R$. The ECD calculations of $\mathbf{1}$ were also carried out to determine the absolute configuration. The result showed that the calculated spectrum of $(8 S, 10 S, 11 S, 13 R)-\mathbf{1}$ agreed with the experimental one, indicating the absolute configuration of 1 to be $8 S, 10 S, 11 S, 13 R$ (Figure 4). Thus, the structure of 1 was determined and named heterocornol $Q$ (1).
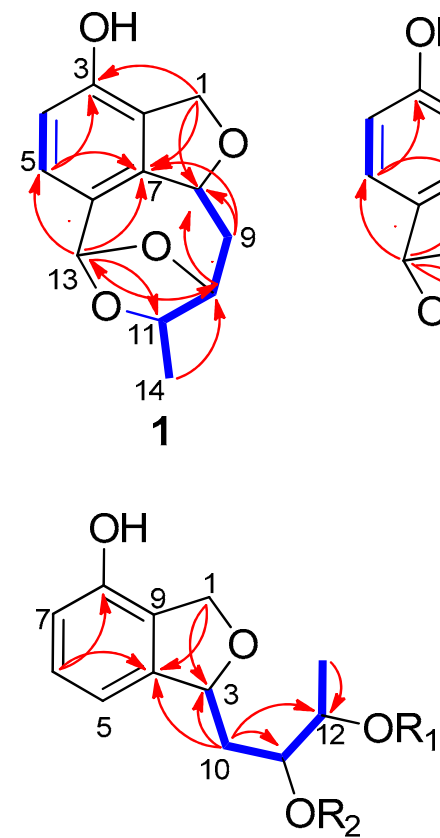

$5 \mathrm{R}_{1}=\mathrm{COCH}_{3}, \mathrm{R}_{2}=\mathrm{H}$

$6 \mathrm{R}_{1}=\mathrm{H}, \mathrm{R}_{2}=\mathrm{COCH}_{3}$

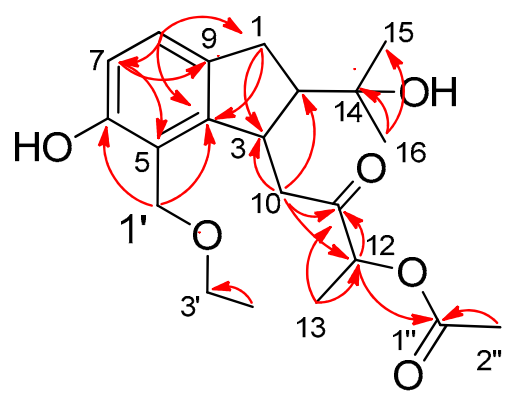

3

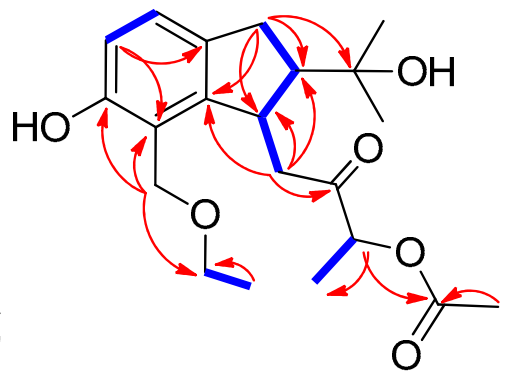

4
2

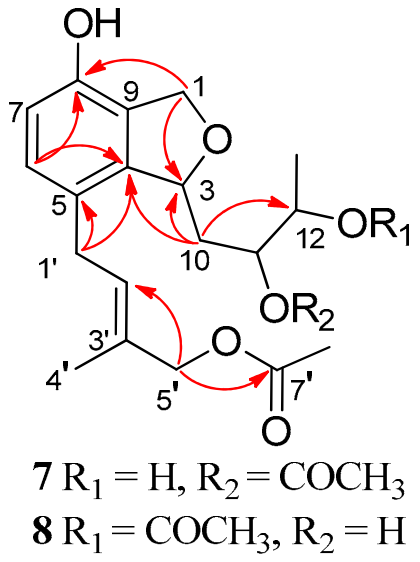

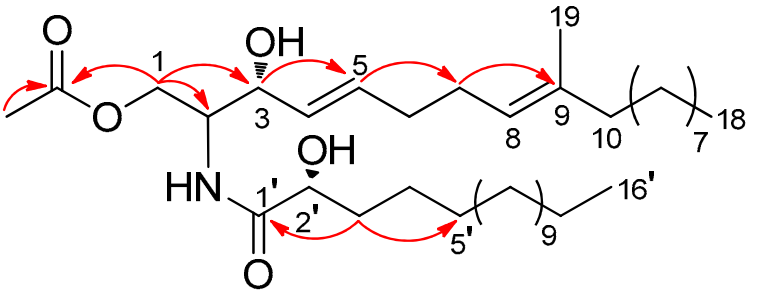

9

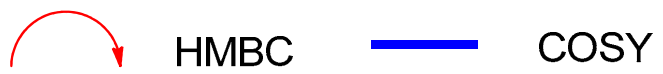

Figure 2. COSY and key HMBC correlations of 1-9. 
Table 1. ${ }^{1} \mathrm{H}$ NMR $(500 \mathrm{MHz})$ data for $1-4$ in $\mathrm{CD}_{3} \mathrm{OD}$.

\begin{tabular}{|c|c|c|c|c|c|c|c|c|}
\hline \multirow[b]{2}{*}{ No. } & \multicolumn{2}{|r|}{1} & \multicolumn{2}{|r|}{2} & \multicolumn{2}{|r|}{3} & \multicolumn{2}{|r|}{4} \\
\hline & $\delta_{\mathrm{C}}$, Type & $\delta_{\mathrm{H}}(J$ in $\mathrm{Hz})$ & $\delta_{\mathrm{C}}$, Type & $\delta_{\mathrm{H}}(J$ in $\mathrm{Hz})$ & $\delta_{\mathrm{C}}$, Type & $\delta_{\mathrm{H}}(J$ in $\mathrm{Hz})$ & $\delta_{\mathrm{C}}$, Type & $\delta_{\mathrm{H}}(J$ in $\mathrm{Hz})$ \\
\hline 1 & $72.4, \mathrm{CH}_{2}$ & 5.12 , dd $(12.1,2.5)$ & $72.1, \mathrm{CH}_{2}$ & 5.11 , dd $(12.0,2.2)$ & $31.7, \mathrm{CH}_{2}$ & $2.81, \mathrm{~d}(16.4)$ & $31.7, \mathrm{CH}$ & $2.83, \mathrm{~d}(8.3)$ \\
\hline & & 4.96, dd $(12.1,2.7)$ & & 4.93, dd $(12.0,3.2)$ & & 3.07, dd $(16.4,8.5)$ & & $3.10, \mathrm{dd}(16.3,8.3)$ \\
\hline 2 & 127.4, C & & $127.8, \mathrm{C}$ & & $55.6, \mathrm{CH}$ & $2.05, \mathrm{~m}$ & $55.5, \mathrm{CH}$ & $2.00, \mathrm{~m}$ \\
\hline 3 & 153.4, C & & $153.5, \mathrm{C}$ & & $40.8, \mathrm{CH}$ & $3.75, \mathrm{dd}(10.6,2.3)$ & $40.9, \mathrm{CH}$ & $3.76, \mathrm{dd}(10.6,2.8)$ \\
\hline 4 & $113.8, \mathrm{CH}$ & $6.58, \mathrm{~d}(7.9)$ & 113.7, $\mathrm{CH}$ & $6.58, \mathrm{~d}(7.9)$ & $147.4, \mathrm{C}$ & & $147.2, \mathrm{C}$ & \\
\hline 5 & 127.1, CH & 7.01, d (7.9) & $126.8, \mathrm{CH}$ & 7.01, d (7.9) & $119.1, \mathrm{C}$ & & $119.1, \mathrm{C}$ & \\
\hline 6 & $129.4, \mathrm{C}$ & & $129.2, \mathrm{C}$ & & $154.8, \mathrm{C}$ & & $154.8, \mathrm{C}$ & $6.63, \mathrm{~d}(8.0)$ \\
\hline 7 & 143.7, C & & 143.7, C & & $114.0, \mathrm{CH}$ & $6.63, \mathrm{~d}(8.1)$ & $114.0, \mathrm{CH}$ & $6.94, \mathrm{~d}(8.0)$ \\
\hline 8 & $82.6, \mathrm{CH}$ & $5.50, \mathrm{dd}(8.3,2.5)$ & $82.5, \mathrm{CH}$ & $5.71, \operatorname{ddt}(10.9,5.6,2.6)$ & $124.2, \mathrm{CH}$ & $6.93, \mathrm{~d}(8.1)$ & $124.2, \mathrm{CH}$ & $2.79, \mathrm{~m}$ \\
\hline \multirow[t]{2}{*}{9} & $39.4, \mathrm{CH}_{2}$ & $2.32, \mathrm{dt}(13.5,4.7)$ & $35.8, \mathrm{CH}_{2}$ & 2.32, ddd $(14.8,5.6,2.5)$ & $134.0, \mathrm{C}$ & & 134.0, C & $2.90, \mathrm{~d}(2.8)$ \\
\hline & & $\begin{array}{l}\text { 1.94, ddd (13.5, } \\
11.3,2.8)\end{array}$ & & 1.97, ddd $(14.8,11.2,4.5)$ & & & & \\
\hline 10 & $77.3, \mathrm{CH}$ & $4.61, \mathrm{q}(6.0)$ & $77.3, \mathrm{CH}$ & $4.40, \mathrm{q}(3.9)$ & $44.2, \mathrm{CH}_{2}$ & $\begin{array}{l}\text { 2.74, dd }(16.2,10.7) \\
\text { 3.01, dd }(16.2,2.4)\end{array}$ & $43.9, \mathrm{CH}_{2}$ & $\begin{array}{c}2.79, \mathrm{~m} \\
2.90, \mathrm{~d}(2.8)\end{array}$ \\
\hline 11 & $81.4, \mathrm{CH}$ & $4.34, \mathrm{t}(2.5)$ & $78.5, \mathrm{CH}$ & $4.28, \mathrm{dd}(6.6,4.4)$ & 208.1, C & & $208.0, C$ & \\
\hline 12 & & & & & $74.7, \mathrm{CH}$ & $5.08, \mathrm{q}(7.2)$ & $75.1, \mathrm{CH}$ & $5.06, \mathrm{q}(7.1)$ \\
\hline 13 & 106.4, $\mathrm{CH}$ & $5.96, \mathrm{~s}$ & 105.3, CH & $5.82, \mathrm{~s}$ & $14.8, \mathrm{CH}_{3}$ & $1.39, \mathrm{~d}(7.2)$ & $14.9, \mathrm{CH}_{3}$ & $1.39, \mathrm{~d}(7.1)$ \\
\hline 14 & 21.1, $\mathrm{CH}_{3}$ & $1.30, \mathrm{~d}(6.2)$ & 13.0, $\mathrm{CH}_{3}$ & $1.51, \mathrm{~d}(6.6)$ & $72.6, \mathrm{C}$ & & $72.5, \mathrm{C}$ & \\
\hline 15 & & & & & $25.3, \mathrm{CH}_{3}$ & $0.91, \mathrm{~s}$ & 25.3, $\mathrm{CH}_{3}$ & $0.91, \mathrm{~s}$ \\
\hline 16 & & & & & $25.7, \mathrm{CH}_{3}$ & $1.05, \mathrm{~s}$ & $25.7, \mathrm{CH} 3$ & $1.05, \mathrm{~s}$ \\
\hline \multirow[t]{2}{*}{$1^{\prime}$} & & & & & $64.3, \mathrm{CH}_{2}$ & $4.48, \mathrm{~d}(10.6)$ & $64.3, \mathrm{CH}_{2}$ & $4.48, \mathrm{~d}(10.6)$ \\
\hline & & & & & & $4.60, \mathrm{~d}(10.6)$ & & $4.60, \mathrm{~d}(10.6)$ \\
\hline $3^{\prime}$ & & & & & $65.5, \mathrm{CH}_{2}$ & $3.57, \mathrm{~d}(7.0)$ & $65.4, \mathrm{CH}_{2}$ & 3.56, dd $(7.1,3.5)$ \\
\hline $4^{\prime}$ & & & & & $14.1, \mathrm{CH}_{3}$ & $1.20, \mathrm{~d}(7.0)$ & $14.1, \mathrm{CH}_{3}$ & $1.19, \mathrm{~d}(6.7)$ \\
\hline \multirow[t]{2}{*}{$\mathrm{AcO}$} & & & & & $170.7, \mathrm{C}$ & & $170.7, \mathrm{C}$ & \\
\hline & & & & & $19.1, \mathrm{CH}_{3}$ & $2.09, \mathrm{~s}$ & $19.2, \mathrm{CH}_{3}$ & $2.10, \mathrm{~s}$ \\
\hline
\end{tabular}

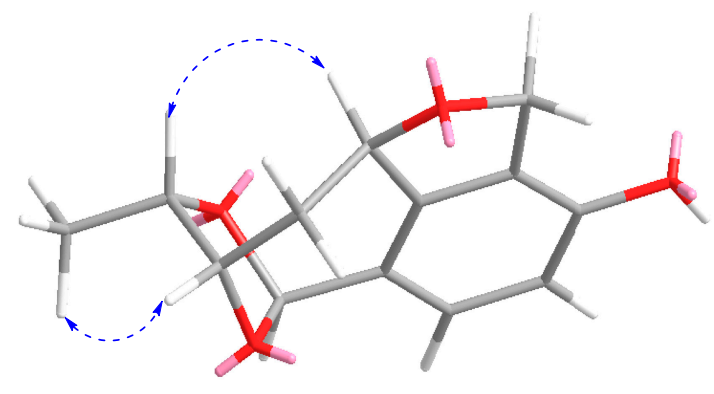

1

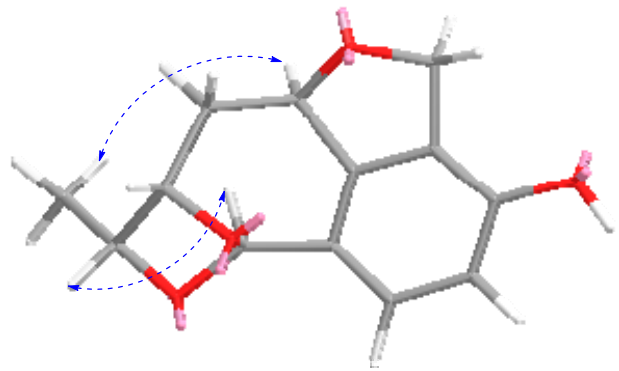

2

Figure 3. Key NOESY correlations of compounds 1 and 2.

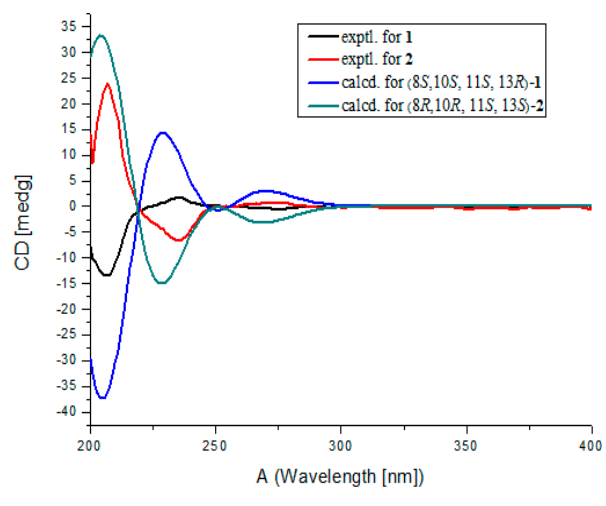

(a)

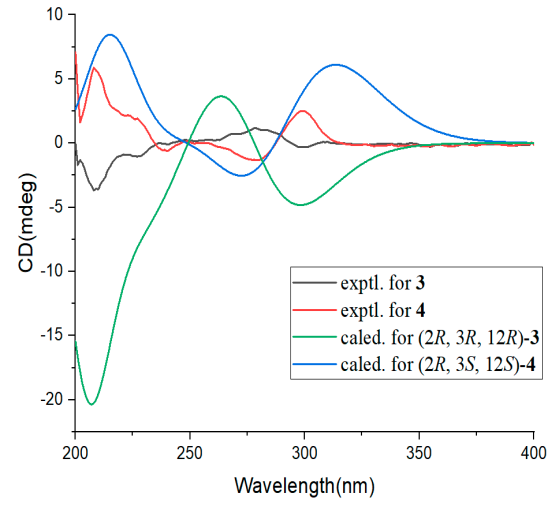

(b)

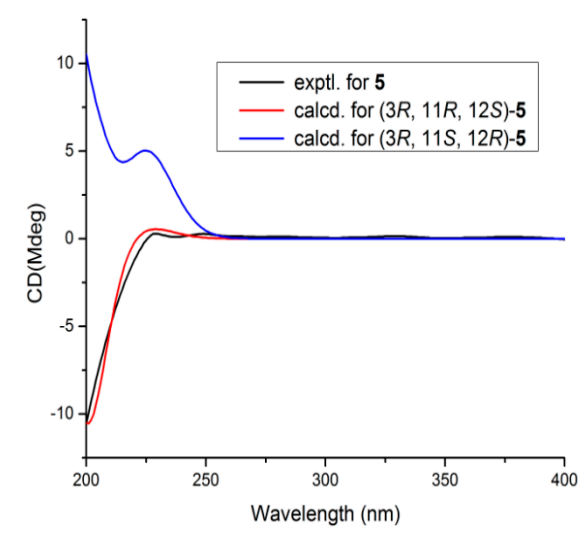

(c)

Figure 4. Comparison between calculated and experimental ECD spectra of 1-5. (a) for $\mathbf{1}$ and 2; (b) for 3 and 4 ; (c) for 5.

Compound 2 was isolated as a white amorphous solid, and possessed the same molecular formula $\mathrm{C}_{13} \mathrm{H}_{14} \mathrm{O}_{4}$ as that of $\mathbf{1}$, based upon its HRESIMS at $m / z 233.0806[\mathrm{M}-\mathrm{H}]^{-}$ and ${ }^{13} \mathrm{C}$ NMR data (Figure S8). The high resemblances of the 1D and 2D NMR data (Table 1 and Figures S9-S14) of $\mathbf{1}$ and 2, indicating that both compounds had the same 
planar structures [20]. Compared with 1, the main difference occurred at the configuration at $\mathrm{C}-8, \mathrm{C}-10, \mathrm{C}-11$, and $\mathrm{C}-13$, which was proved by the carbon chemical shifts of $\mathrm{C}-8$ $\left(\Delta \delta_{\mathrm{C}}(-0.1 \mathrm{ppm}), \mathrm{C}-10\left(\Delta \delta_{\mathrm{C}} 0.0 \mathrm{ppm}\right), \mathrm{C}-11\left(\Delta \delta_{\mathrm{C}}-4.1 \mathrm{ppm}\right), \mathrm{C}-13\left(\Delta \delta_{\mathrm{C}}-1.1 \mathrm{ppm}\right)\right.$, and $\mathrm{C}-14\left(\Delta \delta_{\mathrm{C}}-8.1 \mathrm{ppm}\right)$.The NOESY correlations of $\mathrm{H}-8 / \mathrm{H}_{3}-14$ (Figures 3 and S14) along with the NOESY correlations for $\mathrm{H}-13 / \mathrm{H}-11$ revealed that $\mathrm{H}-8$ and $\mathrm{H}_{3}-14$ were positioned on the opposite face relative to $\mathrm{H}-10$ and $\mathrm{H}-11$. On the basis of the above evidence and the presumed biosynthetic pathway, we suggest that the relative configuration of $\mathbf{2}$ was assigned as $8 R, 10 R, 11 S, 13 S$. This assignment was further confirmed by the calculated ECD spectrum of $(8 R, 10 R, 11 S, 13 S)$-2, the result of which showed good accordance with the experimental one (Figure 4). Thus, the structure of $\mathbf{2}$ was determined and named heterocornol R (2).

Compound 3 was isolated as a white amorphous solid, and the molecular formula was determined to be $\mathrm{C}_{21} \mathrm{H}_{30} \mathrm{O}_{6}$ by HRESIMS, giving a molecular ion peak at $\mathrm{m} / z 401.1955[\mathrm{M}+\mathrm{Na}]^{+}$, indicating seven degrees of unsaturation (Figure S15). The ${ }^{1} \mathrm{H}$ NMR spectrum (Figure S16) revealed characteristic signals for two aromatic protons of a 1,2,3,4-tetrasubstituted benzene $\left[\delta_{\mathrm{H}} 6.93(\mathrm{~d}, J=8.1 \mathrm{~Hz})\right.$ and $\left.6.63(\mathrm{~d}, J=8.1 \mathrm{~Hz})\right]$, and five methyl groups $\left[\delta_{\mathrm{H}} 2.09(\mathrm{~s}), 1.39(\mathrm{~d}\right.$, $J=7.2 \mathrm{~Hz}), 1.2(\mathrm{~d}, J=7.0 \mathrm{~Hz}), 1.05(\mathrm{~s})$, and $0.91(\mathrm{~s})] .{ }^{1} \mathrm{H}$ and ${ }^{13} \mathrm{C}$ NMR spectroscopic data of 3 (Figures S17 and S18) revealed that it possessed the similar structural characteristics with pestalachloride E [21], a chlorinated benzophenone derivative obtained from a marine fungal pestalotiopsis sp. The major difference was that one aldehyde group at C-5 and dichloro-substituted phenol at $\mathrm{C}-3$ in pestalachloride $\mathrm{E}$ was replaced by one ethoxyethane (C-5) and ethyl ketone side chain (C-3) in 3, respectively. This was further confirmed by the HMBC correlations from H-1 ${ }^{\prime}\left(\delta_{\mathrm{H}} 4.60\right)$ to C-4 $\left(\delta_{\mathrm{C}} 147.4\right), \mathrm{C}-6\left(\delta_{\mathrm{C}} 154.8\right), \mathrm{C}-5\left(\delta_{\mathrm{C}} 119.1\right)$, and $\mathrm{C}-3^{\prime}\left(\delta_{\mathrm{C}} 65.5\right)$, from $\mathrm{H}-10\left(\delta_{\mathrm{H}} 3.01\right)$ to $\mathrm{C}-3\left(\delta_{\mathrm{C}} 40.8\right), \mathrm{C}-2\left(\delta_{\mathrm{C}} 55.6\right)$, and $\mathrm{C}-4\left(\delta_{\mathrm{C}} 147.4\right)$, together with the COSY correlations $\mathrm{H}-1 / \mathrm{H}-2 / \mathrm{H}-3 / \mathrm{H}-10$ and $\mathrm{H}-7 / \mathrm{H}-8$. HMBC correlations between $\mathrm{H}-8\left(\delta_{\mathrm{H}} 6.93\right)$ and $\mathrm{C}-1\left(\delta_{\mathrm{C}} 31.7\right), \mathrm{C}-7\left(\delta_{\mathrm{C}} 114.0\right)$, and $\mathrm{C}-4\left(\delta_{\mathrm{C}} 147.4\right)$ and between $\mathrm{H}-13\left(\delta_{\mathrm{H}} 1.39\right)$ and $\mathrm{C}-11\left(\delta_{\mathrm{C}} 208.1\right), \mathrm{C}-12\left(\delta_{\mathrm{C}} 74.7\right)$ and between $\mathrm{H}-16\left(\delta_{\mathrm{H}} 1.05\right)$ and C-14 $\left(\delta_{\mathrm{C}} 72.6\right), \mathrm{C}-2\left(\delta_{\mathrm{C}} 55.6\right)$, and $\mathrm{C}-15\left(\delta_{\mathrm{C}} 25.3\right)$ reconfirmed that the hydroxyl was located at $\mathrm{C}-14$. The planar structure of 3 was confirmed by HSQC, COSY, and HMBC experiments (Figures 2, S19 and S20).

Compound 4 was isolated as a white amorphous solid and had the same molecular formula, $\mathrm{C}_{21} \mathrm{H}_{30} \mathrm{O}_{6}$, as 3 by HRESIMS data (Figure S21). Detailed analyses of its NMR spectroscopic features implied that 3 and 4 had the same planar structures. Analysis of the 2D NMR spectra confirmed the structure of 4 (Figures 2 and S22-S27).

Unfortunately, in the NOESY spectrum, NOE interactions could not be used to determine the different stereoscopic relationship between 3 and 4 . The apparent difference between 3 and $\mathbf{4}$ are the opposite Cotton effects (Figure 4) and the opposite optical rotations. To further assign the absolute configuration of 3 and 4, ECD calculations were performed (Figures 4, S28 and S29). According to the literature [22,23], the ECD band between 260 and $285 \mathrm{~nm}$ is allied with the ${ }^{1} \mathrm{~L}_{\mathrm{b}}$ transition of the aromatic chromophore. The region of the spectrum from 260 to 285 is diagnostic of the configuration of aromatic compounds. The experimental ECD spectrum for compound 3 displays positive Cotton effects at $278 \mathrm{~nm}$ and negative effects at 208 and $300 \mathrm{~nm}$. The calculated ECD spectra for 3 with an $R$ configuration at C-12 showed a negative Cotton effect between 280 and $320 \mathrm{~nm}$. The CD spectrum of 4 showed negative ( 229 and $240 \mathrm{~nm}$ ) and positive ( 300 and $208 \mathrm{~nm}$ ) Cotton effects, indicating that the $C-12$ of 4 was represented as $S$. As a result, the calculated ECD curve for $2 R, 3 R, 12 R-3$ was the best match with 3 , and $2 R, 3 S, 12 S-4$ was the best match with 4 (Figures 4 and S30-S35).

The molecular formula of 5 was assigned to be $\mathrm{C}_{14} \mathrm{H}_{18} \mathrm{O}_{5}$ on the basis of the HRESIMS ion at $m / z 289.1047[\mathrm{M}+\mathrm{Na}]^{+}$and ${ }^{13} \mathrm{C} \mathrm{NMR}$ data (Figure S36). The ${ }^{1} \mathrm{H}$ and ${ }^{13} \mathrm{C}$ NMR data of 5 (Figures S37-S39) were similar to those of vaccinol O [19]. The major difference was due to the presence of signals of the acetyl moiety $\left(\delta_{\mathrm{H}} 2.04, \delta_{\mathrm{C}} 172.5\right.$, and 21.2) in 5, instead of the carbonyl group in vaccinol $\mathrm{O}$. In addition, signals for an isopentyl unit were absent in the NMR spectra of 5 (Tables 2 and 3), which was confirmed by COSY and HMBC experiments 
(Figures S40-S42). In addition, the CD spectrum of 5 exhibited a negative Cotton effect at $204 \mathrm{~nm}$ in accordance with that of vaccinol O [19], which allowed assignment of the $3 R$ absolute configuration (Figure 4 ). The coupling constant $J_{\mathrm{H}-11 / \mathrm{H}-12}=4.2 \mathrm{~Hz}$ revealed that the relative configurations of C-11 and C-12 in 5 were suggested as an erythro [24]. In order to discriminate between $(11 R, 12 S)-5$ and $(11 S, 12 R)-5$, the electronic circular dichroism (ECD) spectrum of 5 was calculated and compared with the experimental spectra. As a result, the calculated spectrum of $(11 R, 12 S)-5$ matched well with the experimental data (Figure 4), indicating absolute configuration of $\mathbf{5}$, to be $3 R, 11 R, 12 S$.

Table 2. ${ }^{1} \mathrm{H}$ NMR $(500 \mathrm{MHz})$ data for 5-9.

\begin{tabular}{|c|c|c|c|c|c|}
\hline & $5^{a}$ & $6^{a}$ & $7^{a}$ & $8^{a}$ & $9^{b}$ \\
\hline No. & $\delta_{\mathbf{H}}(J$ in $\mathrm{Hz})$ & $\delta_{\mathrm{H}}(J$ in $\mathrm{Hz})$ & $\delta_{\mathrm{H}}(J$ in $\mathrm{Hz})$ & $\delta_{\mathbf{H}}(J$ in $\mathrm{Hz})$ & $\delta_{\mathrm{H}}(J$ in $\mathrm{Hz})$ \\
\hline \multirow[t]{2}{*}{1} & $5.06, \mathrm{dd}(12.0,2.7)$ & $5.04, \mathrm{dd}(12.3,2.8)$ & 5.10, dd $(12.0,3.1)$ & $5.08, \mathrm{dd}(12.1,2.7)$ & $4.32, \mathrm{dt}(8.1,4.0)$ \\
\hline & $4.97, \mathrm{~d}(12.0)$ & 4.97, dd $(12.3)$ & $4.94, \mathrm{~d}(12.0)$ & $4.98, \mathrm{~d}(12.1)$ & $4.19, \mathrm{dt}(8.1,3.8)$ \\
\hline 2 & & & & & $4.21, \mathrm{~m}$ \\
\hline 3 & $5.39, \mathrm{~d}(9.9)$ & 5.18, dd $(10.0,2.1)$ & 5.43, brd $(9.0)$ & 5.55, brd $(9.0)$ & 4.20 , brs \\
\hline 4 & & & & & $5.49, \mathrm{dd}(15.4,6.4)$ \\
\hline 5 & 6.67, d (7.7) & $6.67, \mathrm{~d}(7.8)$ & & & $5.77, \mathrm{dt}(15.4,6.4)$ \\
\hline 6 & $7.11, \mathrm{t}(7.7)$ & $7.11, \mathrm{t}(7.8)$ & $6.88, \mathrm{~d}(8.1)$ & 6.87, d (8.1) & $2.08, \mathrm{~m}$ \\
\hline 7 & $6.66, \mathrm{~d}(7.7)$ & 6.66, d (7.8) & 6.60, d (8.1) & $6.60, \mathrm{~d}(8.1)$ & \\
\hline 8 & & & & & $5.08, \mathrm{~d}(6.4)$ \\
\hline \multirow[t]{2}{*}{10} & 1.84, ddd $(14.3,10.3,2.3)$ & $2.08, \mathrm{~m}$ & $1.84, \mathrm{dd}(6.7,4.3)$ & $2.13, \mathrm{~m}$ & $1.95, \mathrm{~d}(7.7)$ \\
\hline & 1.71 , ddd $(14.3,10.0,2.5)$ & $1.86, \mathrm{dt}(4.5,2.5)$ & & & \\
\hline 11 & 3.93, ddd $(10.3,4.2,2.5)$ & 3.93, ddd $(10.2,4.5,2.3)$ & $5.03, \operatorname{ddd}(10.0,4.3,2.0)$ & 5.04, ddd $(10.0,4.7,2.6)$ & $1.24, \mathrm{~m}$ \\
\hline 12 & $4.85, \mathrm{~m}$ & $5.05 \mathrm{~m}$ & $4.87, \mathrm{dd}(6.5,4.3)$ & $4.89, \mathrm{dd}(6.4,4.7)$ & $1.26, \mathrm{~m}$ \\
\hline 13 & $1.21, \mathrm{~d}(6.5)$ & $1.13, \mathrm{~d}(6.5)$ & $1.12, \mathrm{~s}$ & $1.23, \mathrm{~s}$ & $1.32, \mathrm{~m}$ \\
\hline 1 & & & $3.25, \mathrm{~m}$ & $3.36, \mathrm{~m}$ & \\
\hline 2 & & & $5.54, \mathrm{t}(7.0)$ & $5.45, \mathrm{t}(6.5)$ & $4.11, \mathrm{dt}(8.1,3.8)$ \\
\hline 3 & & & & & $1.61, \mathrm{~m}, 1.81, \mathrm{~m}$ \\
\hline 4 & & & $2.03, \mathrm{~s}$ & $2.06, \mathrm{~s}$ & $1.42, \mathrm{~m}$ \\
\hline 5 & & & $4.48, \mathrm{~s}$ & $4.69, \mathrm{~s}$ & $1.26, \mathrm{~m}$ \\
\hline $11-\mathrm{OAc}$ & & $2.09, \mathrm{~s}$ & $1.61, \mathrm{~s}$ & & $1.34, \mathrm{~m}$ \\
\hline $12-\mathrm{OAc}$ & $2.04, \mathrm{~s}$ & & & $1.62, \mathrm{~s}$ & \\
\hline 5-OAc & & & $2.02, \mathrm{~s}$ & $2.04, \mathrm{~s}$ & \\
\hline $1-\mathrm{OAc}$ & & & & & $2.06, \mathrm{~m}$ \\
\hline $14 \sim 17$ & & & & & $1.24 \sim 1.42$ \\
\hline 18 & & & & & $0.88, \mathrm{t}(7.0)$ \\
\hline 19 & & & & & $1.58, \mathrm{brs}$ \\
\hline
\end{tabular}

${ }^{\text {a }} \mathrm{NMR}$ data for compounds $5-8$ in $\mathrm{CD}_{3} \mathrm{OD},{ }^{\mathrm{b}} \mathrm{NMR}$ data for compound 9 in $\mathrm{CDCl}_{3}$ ( $\delta$ in ppm and $J$ in $\mathrm{Hz}$ ).

Compound 6 had the same molecular formula as 5, which was established by their HRESIMS together with the ${ }^{13} \mathrm{C}$ NMR data (Figure S43). Its ${ }^{1} \mathrm{H}$ and ${ }^{13} \mathrm{C}$ NMR data (Tables 2 and 3, Figures S44 and S45) closely resembled those of 5, except for an acetyl moiety at C-12 $\left(\delta_{\mathrm{C}} 75.3\right)$ in 5 and $\mathrm{C}-11\left(\delta_{\mathrm{C}} 76.2\right)$ in 6 . Compared with 5, chemical shift of $\mathrm{C}-10\left(\delta_{\mathrm{C}} 37.1\right), \mathrm{C}-11$ $\left(\delta_{\mathrm{C}} 69.7\right), \mathrm{C}-12\left(\delta_{\mathrm{C}} 76.2\right)$, and $\mathrm{C}-13\left(\delta_{\mathrm{C}} 18.4\right)$ of 6 were shifted upfield $(\Delta 3.3 \mathrm{ppm}, \Delta 5.6 \mathrm{ppm})$ and downfield $(\Delta 5.2 \mathrm{ppm}, \Delta 3.3 \mathrm{ppm})$, respectively. The planar structure of 6 was confirmed by HSQC, COSY, and HMBC experiments (Figures 2, S46 and S47). The shared biogenesis and similar chemical shifts and coupling constants of 6 and 5 suggested the 6 had the same relative configurations for C-3, C-11, and C-12 as those of 5. In addition, compound 6 showed the similar specific rotation $\left([\alpha]_{\mathrm{D}}^{25}-2.5(c 0.1, \mathrm{MeOH})\right)$ to that of $5\left([\alpha]_{\mathrm{D}}^{25}-2.4(c\right.$ $0.20, \mathrm{MeOH})$ ), which indicated compound 6 had the same configuration. Given that both 5 and $\mathbf{6}$ were isolated from the same strain, the absolute configuration of $\mathbf{6}$ was deduced as $3 R, 11 R, 12 S$.

The molecular formula of 7 and 8 were assigned as $\mathrm{C}_{21} \mathrm{H}_{28} \mathrm{O}_{7}$, by analysis of their HRESIMS and ${ }^{13} \mathrm{C}$ NMR data (Figures S48 and S53). Their NMR spectroscopic features implied that 7 and 8 were a pair of regioisomers. Moreover, the 1D NMR data of 7 and 8 were similar to those of 5 (Figures S49-S51 and S54-S56). The only difference was due to the presence of signals of the additional isopentyl unit and acetyl moiety in 8 . Thus, it suggested that 8 was a derivative of 5 , which was confirmed by the HMBC correlation from H-1 ${ }^{\prime}\left(\delta_{\mathrm{H}} 3.36\right)$ to $\mathrm{C}-4\left(\delta_{\mathrm{C}} 141.8\right), \mathrm{C}-6\left(\delta_{\mathrm{C}} 130.3\right), \mathrm{C}-5\left(\delta_{\mathrm{C}} 126.0\right)$, and C-3' $\left(\delta_{\mathrm{C}} 132.4\right)$, from $\mathrm{H}-5^{\prime}\left(\delta_{\mathrm{H}} 4.69\right)$ to $\mathrm{C}-4^{\prime}\left(\delta_{\mathrm{C}} 21.6\right), \mathrm{C}-2^{\prime}\left(\delta_{\mathrm{C}} 129.7\right)$, and $5^{\prime}-\mathrm{OAc}\left(\delta_{\mathrm{C}} 172.8\right)$. Compared with 7 , the only difference was that 7 had an acetyl group at $\mathrm{C}-11$, while 8 had an acetyl group at C-12, which was confirmed by the HMBC correlations of $\mathrm{H}-12\left(\delta_{\mathrm{H}} 4.89\right)$ with $\mathrm{C}-10\left(\delta_{\mathrm{C}} 35.0\right)$, 
C-13 $\left(\delta_{\mathrm{C}} 15.0\right)$, and 12-OAc $\left(\delta_{\mathrm{C}} 171.4\right)$ in 8 (Figure 2, Figures S52 and S57). Comparison of the analogous chemical shifts and coupling constants between 5 and 8 , and between 6 and 7 , together with biogenetic considerations based on their coisolation $[19,25]$, we suggest that the absolute configuration of $\mathbf{7}$ and $\mathbf{8}$ to have $3 R, 11 R, 12 S$ configurations, which are the same as those of 5 .

Table 3. ${ }^{13} \mathrm{C}$ NMR (125 MHz) data for 5-9.

\begin{tabular}{|c|c|c|c|c|c|}
\hline & $5^{a}$ & $6^{a}$ & $7^{a}$ & $8^{a}$ & $9^{b}$ \\
\hline No. & $\delta_{\mathrm{C}}$, Type & $\delta_{\mathrm{C}}$, Type & $\delta_{\mathrm{C}}$, Type & $\delta_{\mathrm{C}}$, Type & $\delta_{\mathrm{C}}$, Type \\
\hline 1 & \multirow[t]{2}{*}{$71.4, \mathrm{CH}_{2}$} & \multirow[t]{2}{*}{$71.6, \mathrm{CH}_{2}$} & \multirow[t]{2}{*}{$72.8, \mathrm{CH}_{2}$} & \multirow[t]{2}{*}{$70.0, \mathrm{CH}_{2}$} & $62.9, \mathrm{CH}_{2}$ \\
\hline 2 & & & & & $53.0, \mathrm{CH}$ \\
\hline 3 & $82.2, \mathrm{CH}$ & $82.2, \mathrm{CH}$ & $84.1, \mathrm{CH}$ & $83.2, \mathrm{CH}$ & $73.0, \mathrm{CH}$ \\
\hline 4 & $145.4, \mathrm{C}$ & $145.1, \mathrm{C}$ & $142.8, \mathrm{C}$ & $141.8, \mathrm{C}$ & $128.2, \mathrm{CH}$ \\
\hline 5 & 113.0, CH & 113.0, CH & 126.0, C & $126.0, \mathrm{C}$ & $134.4, \mathrm{CH}$ \\
\hline 6 & $130.2, \mathrm{CH}$ & $130.3, \mathrm{CH}$ & $130.7, \mathrm{CH}$ & $130.3, \mathrm{CH}$ & $31.9, \mathrm{CH}_{2}$ \\
\hline 7 & $114.9, \mathrm{CH}$ & 115.0, CH & $115.6, \mathrm{C}$ & $115.2, \mathrm{CH}$ & $27.5, \mathrm{CH}_{2}$ \\
\hline 8 & $152.9, \mathrm{C}$ & 153.0, C & 151.3, C & 151.3, C & $123.1, \mathrm{CH}$ \\
\hline 9 & $126.1, \mathrm{C}$ & 126.3, C & 126.1, C & $126.5, \mathrm{C}$ & 136.2, C \\
\hline 10 & $40.4, \mathrm{CH}_{2}$ & $37.1, \mathrm{CH}_{2}$ & $38.9, \mathrm{CH}_{2}$ & $35.0, \mathrm{CH}_{2}$ & $39.7, \mathrm{CH}_{2}$ \\
\hline 11 & $71.0, \mathrm{CH}$ & $69.7, \mathrm{CH}$ & $74.7, \mathrm{CH}$ & $72.4, \mathrm{CH}$ & $28.0, \mathrm{CH}_{2}$ \\
\hline 12 & $75.3, \mathrm{CH}$ & $76.2, \mathrm{CH}$ & $71.5, \mathrm{CH}$ & $74.7, \mathrm{CH}$ & $29.4, \mathrm{CH}_{2}$ \\
\hline 13 & \multirow[t]{8}{*}{$15.1, \mathrm{CH}_{3}$} & \multirow[t]{8}{*}{$18.4, \mathrm{CH}_{3}$} & $15.0, \mathrm{CH}_{3}$ & $15.0, \mathrm{CH}_{3}$ & $29.4, \mathrm{CH}_{2}$ \\
\hline 1 & & & $31.3, \mathrm{CH}_{2}$ & $31.2, \mathrm{CH}_{2}$ & $174.6, \mathrm{C}$ \\
\hline 2 & & & $128.7, \mathrm{CH}$ & $129.7, \mathrm{CH}$ & $72.2, \mathrm{CH}$ \\
\hline 3 & & & $132.5, \mathrm{C}$ & $132.4, \mathrm{C}$ & $34.9, \mathrm{CH}_{2}$ \\
\hline 4 & & & $21.2, \mathrm{CH}_{3}$ & 21.6, $\mathrm{CH}_{3}$ & $25.0, \mathrm{CH}_{2}$ \\
\hline 5 & & & \multirow[t]{3}{*}{$70.9, \mathrm{CH}_{2}$} & \multirow[t]{3}{*}{$64.7, \mathrm{CH}_{3}$} & $28.0, \mathrm{CH}_{2}$ \\
\hline $6 \sim 15$ & & & & & $29.7 \sim 31.9$ \\
\hline 16 & & & & & $14.1, \mathrm{CH}_{3}$ \\
\hline $11-\mathrm{AcO}$ & & & \multirow[t]{3}{*}{$\begin{array}{c}172.4, \mathrm{C} \\
20.8, \mathrm{CH}_{3}\end{array}$} & & \\
\hline $12-\mathrm{AcO}$ & $172.5, \mathrm{C}$ & 172.7, C & & $171.4, \mathrm{C}$ & \\
\hline \multirow{3}{*}{ 5-AcO } & $21.2, \mathrm{CH}_{3}$ & $21.1, \mathrm{CH}_{3}$ & & $20.8, \mathrm{CH}_{3}$ & \\
\hline & & & \multirow{2}{*}{$\begin{array}{c}172.8, \mathrm{C} \\
21.2, \mathrm{CH}_{3}\end{array}$} & $172.8, \mathrm{C}$ & \\
\hline & & & & $20.8, \mathrm{CH}_{3}$ & \\
\hline \multirow{2}{*}{$1-\mathrm{AcO}$} & & & & & $171.3, \mathrm{C}$ \\
\hline & & & & & $20.9, \mathrm{CH}_{3}$ \\
\hline $14 \sim 17$ & & & & & $\begin{array}{c}22.7 \sim 31.9, \\
\mathrm{CH}_{2}\end{array}$ \\
\hline 18 & & & & & $14.1, \mathrm{CH}_{3}$ \\
\hline 19 & & & & & $16.0, \mathrm{CH}_{3}$ \\
\hline
\end{tabular}

a NMR data for compounds 5-8 in $\mathrm{CD}_{3} \mathrm{OD},{ }^{\mathrm{b}} \mathrm{NMR}$ data for compound $\mathbf{9}$ in $\mathrm{CDCl}_{3}(\delta$ in ppm and $J$ in $\mathrm{Hz})$.

Compound 9, an amorphous powder, possessed a molecular formula of $\mathrm{C}_{37} \mathrm{H}_{69} \mathrm{NO}_{5}$ based on its ${ }^{13} \mathrm{C}$ NMR data and HRESIMS $m / z$ 608.5251 [M + H] ${ }^{+}$(Figures S58 and S59). The ${ }^{1} \mathrm{H}$ NMR (Table 2 and Figure S60) spectrum of 9 exhibited an amide proton $\left[\delta_{\mathrm{H}} 6.91\right.$ $(\mathrm{NH}, \mathrm{d}, J=8.0 \mathrm{~Hz})]$, two disubstituted olefinic protons $\left[\delta_{\mathrm{H}} 5.77(1 \mathrm{H}, \mathrm{dt}, J=15.4,6.4 \mathrm{~Hz})\right.$ and $\left.\delta_{\mathrm{H}} 5.49(1 \mathrm{H}, \mathrm{dt}, J=15.4,6.4 \mathrm{~Hz})\right]$, a trisubstituted olefinic proton $\left[\delta_{\mathrm{H}} 5.08(1 \mathrm{H}, \mathrm{d}\right.$, $J=6.4 \mathrm{~Hz})]$, one oxygenated methylene $\left[\delta_{\mathrm{H}} 4.32(1 \mathrm{H}, \mathrm{dt}, J=8.1,4.0 \mathrm{~Hz})\right.$ and $\delta_{\mathrm{H}} 4.19(1 \mathrm{H}$, $\mathrm{dt}, J=8.1,3.8 \mathrm{~Hz})]$, two oxygenated methine $\left[\delta_{\mathrm{H}} 4.20(1 \mathrm{H}, \mathrm{brs})\right.$ and $\delta_{\mathrm{H}} 4.11(1 \mathrm{H}, \mathrm{dt}, J=8.1$, $3.8 \mathrm{~Hz})]$, aliphatic methylenes $\left(\delta_{\mathrm{H}} 1.24 \sim 1.42\right)$. Additionally, resonances for three methyl groups, including an olefinic methyl group $\left(\delta_{\mathrm{H}} 1.58\right.$, brs $)$ and two terminal methyl groups $\left[\delta_{\mathrm{H}} 0.88(6 \mathrm{H}, \mathrm{t}, J=7.0 \mathrm{~Hz})\right]$, were observed. Analysis of the ${ }^{13} \mathrm{C}$ NMR data and HSQC spectra (Figures S61 and S62) revealed the existence of characteristic signals resonances including an amide carbonyl at $\delta_{\mathrm{C}} 173.9$, methine carbons at $\delta_{\mathrm{C}} 53.0$, and aliphatic carbons at $\delta_{\mathrm{C}}$ 22.7 29.7. Detailed analysis of these aforementioned data of 9 suggested it was very similar to those of the previously reported ceramide compound [24], $\left(2 S, 2^{\prime} R, 3 R, 4 E\right.$, $8 E)-\mathrm{N}-2^{\prime}$-Hydroxyhexadecanoyl-2-amino-9-methyl-4, 8-octadecadiene-1,3-diol. The major 
differences are the presence of an additional acetyl group of protons $\left(\delta_{\mathrm{H}} 2.05,20.9\right.$, and 171.3) in $\mathbf{9}$, indicating that 9 was a 1-O-acetyl derivative of ceramide compound. Combined with the 2D NMR spectra data, an acetyl group was suggested at C-1 in 9, which was further confirmed by the HMBC correlation of $\mathrm{H}-1\left(\delta_{\mathrm{H}} 4.32\right.$ and 4.19$)$ with $\mathrm{C}-2\left(\delta_{\mathrm{C}} 53.0\right), \mathrm{C}-3$ $\left(\delta_{\mathrm{C}} 73.0\right)$, and $\mathrm{C}-1{ }^{\prime \prime}\left(\delta_{\mathrm{C}} 171.3\right)$ (Figures 2 and S63). Furthermore, based on the $J$ values for $\mathrm{H}-4\left(\delta_{\mathrm{H}} 5.49, \mathrm{dd}, J=15.4,6.4 \mathrm{~Hz}\right)$, the geometries of the double bonds for $\mathrm{H}-4 / \mathrm{H}-5$ was trans. Compared to the NMR data from $\left(2 S, 2^{\prime} R, 3 R, 4 E, 8 E\right)-\mathrm{N}-2^{\prime}$-Hydroxyhexadecanoyl-2-amino9-methyl-4,8-octadecadiene-1,3-diol [26,27], the chemical shift value of the olefinic methyl group at C-9 $\left(\delta_{\mathrm{C}} 16.0\right)$ in compound 9 suggests that the double bond at C-8 is $E$ geometry. The length of the fatty acid was determined by the characteristic peaks at $m / z 253,296,314$, 336 in the EI-MS (Figures 5 and S59) [28]. According to the literature [29] and our NMR data, the chemical shift of C-3 and C-2' in ceramide compound were almost superimposed with configuration of C-3 and C-2'. Comparing the coupling constant of $\mathrm{H}-2$ and $\mathrm{H}-3$, and ${ }^{13} \mathrm{C}$ NMR data of the synthetic $\left(2 S, 2{ }^{\prime} R, 3 R, 4 E, 8 E\right)-\mathrm{N}-2^{\prime}$-Hydroxyhexadecanoyl-2-amino9-methyl-4, 8-octadecadiene-1,3-diol, the configuration of 9 was deduced. Thus, 9 was determined and named pestalotiopsisamide.

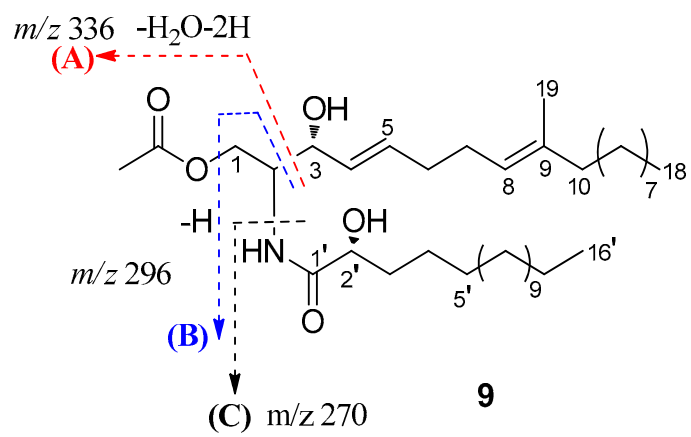

Figure 5. Observed key mass fragments of ceramide 9.

Polyketides are common biosynthetic precursor in the process of synthesizing aromatics and macrolides in microorganisms. Compounds 1-8 were formed via different polyketide precursors by polyketide synthases. Presumed polyketide precursors are considered to be biogenetically derived from acetyl-CoA by reduction, dehydration, oxygenation, and cyclization to form the core skeleton. Next, presumed polyketide precursors underwent reduction to form a vicinal diol (an intermediate), which could generate a dihydroisobenzofuran through reduction and dehydration. Finally, the dihydroisobenzofuran undergoes dehydration and nucleophilic addition to yielded 1 or 2 (Scheme 1), featuring a novel $6 / 5 / 7 / 5$ tetracyclic polyketide derivatives.

The isolated compounds (1-9 and 12) were evaluated for their cytotoxic activities against four human cancer cell lines (Hela, A549, HCT-8, A2780) via MTT assay. However, none of them showed obvious cytotoxicities. They were also tested with their antimicrobial activities against three bacteria and one fungi using a micro broth dilution method (Table 4). Only compound $\mathbf{1 2}$ showed antibacterial activities against Gram-positive bacteria Staphylococcus aureus and Bacillus subtilis and Gram-negative bacteria Escherichia coli, with MIC values ranging from 25 to $50 \mu \mathrm{g} / \mathrm{mL}$. Moreover, 12 also exhibited weak antifungal activities against Candida albicans with MIC values $100 \mu \mathrm{g} / \mathrm{mL}$.

Anti-inflammatory in vitro screening tests activities revealed that 7 and 8 could inhibit the production of LPS-induced NO in RAW 264.7 cells significantly (Figure 6A,B) with no cytotoxicity, comparable to the positive drug dexamethasone (DXM, $33 \mu \mathrm{M})$. Further Western blotting analysis showed $\mathbf{7}$ and $\mathbf{8}$ markedly suppressed the iNOS protein expression in LPS-induced RAW 264.7 cells in a concentration-dependent manner (Figure 6C,D). The result showed that the two new polyketide derivatives, heterocornols $\mathrm{T}$ and $\mathrm{X}$ ( 7 and 8 ), might serve as potential leads for development of anti-inflammatory activity. 


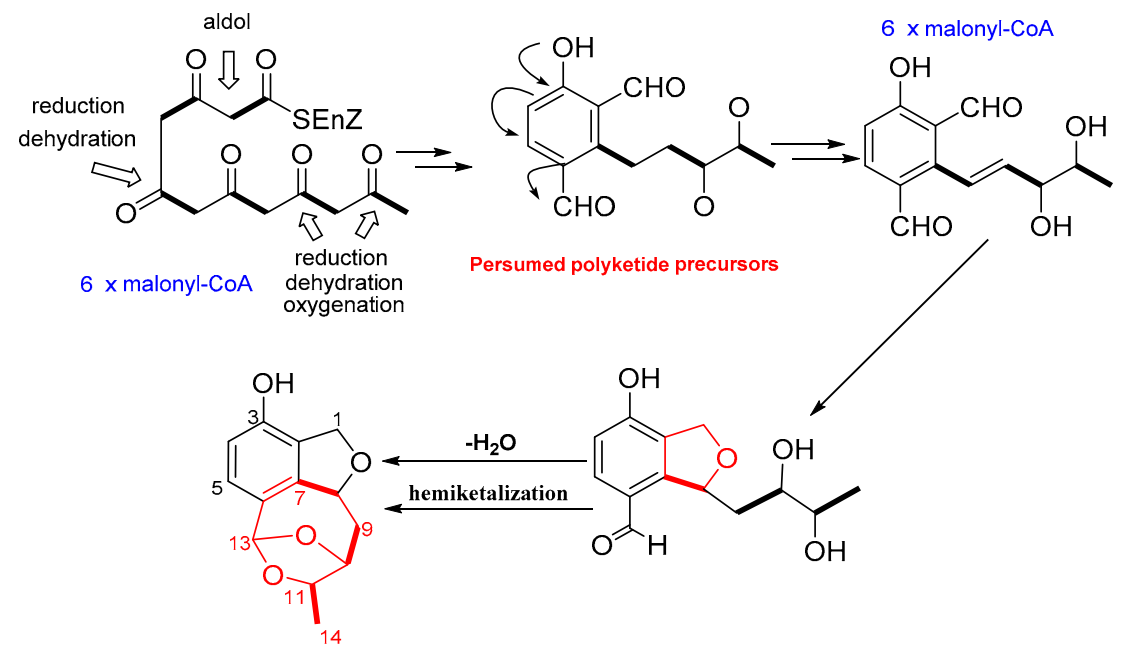

1,2

Scheme 1. Plausible Biosynthetic Pathway of compounds 1 and 2.

Table 4. Antibacterial activity of the compounds (MIC, $\mu \mathrm{g} / \mathrm{mL}$ ).

\begin{tabular}{ccccc}
\hline Strains & S. aureus & B. subtilis & E. coli & C. albicans \\
\hline 12 & 50 & 25 & 25 & 100 \\
Positive & $0.25^{\mathrm{a}}$ & $0.13^{\mathrm{a}}$ & $0.13^{\mathrm{a}}$ & $1.0^{\mathrm{b}}$ \\
\hline
\end{tabular}

${ }^{\text {a }}$ Ciprofloxacin; ${ }^{\text {b }}$ Amphotericin.
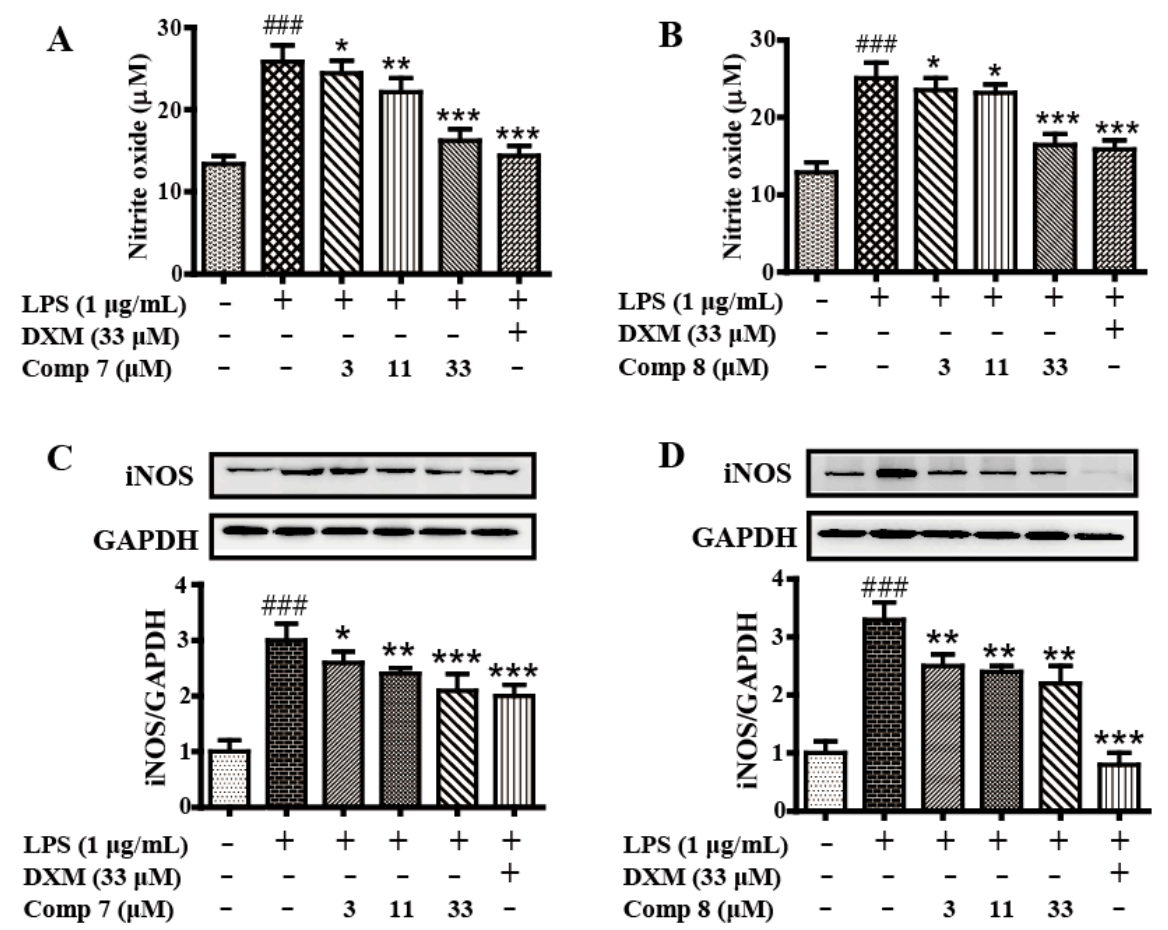

Figure 6. The anti-inflammatory activity of compounds 7 and 8. Cells were pretreated with both compounds 7 and 8 differently concentrations $(0,3,11,33 \mu \mathrm{M})$ and DXM $(33 \mu \mathrm{M})$ for $2 \mathrm{~h}$, then stimulated with or without LPS $(1 \mu \mathrm{g} / \mathrm{mL})$ for $24 \mathrm{~h}$. The culture medium was collected to detect the concentrations of nitrite with Griess agent $(\mathbf{A}, \mathbf{B})$. Protein levels of iNOS were evaluated by Western blot (C,D). The data represent the means \pm S.E. of three independent experiments. (\#\#\# $p<0.001$ was compared to control. ${ }^{*} p<0.05,{ }^{* *} p<0.01,{ }^{* * *} p<0.001$ compared to LPS group). 


\section{Materials and Methods}

\subsection{General Experimental Procedures}

Optical rotations were determined using an AntonPaar MCP500 polarimeter. UV spectra were measured with a Shimadzu UV-2600 PC spectrometer. IR spectra were recorded on a Shimadzu IR Affinity-1 spectrometer with KBr pellets. 1D and 2D NMR spectra were collected on a Bruker DRX-500 spectrometer, $\delta$ in ppm rel. to TMS, $J$ in Hz. HRESIMS were performed using a Bruker maXis TOF-Q mass spectrometer (Bruker, Daltonics, Billerica, MA, USA). Silica gel (100-200 mesh, 200-300 mesh, Qingdao Marine Chemical Ltd., Qingdao, China), Sephadex LH-20 (GE Healthcare Bio-sciences AB, Uppsala, Sweden), YMC*GEL ODS-A (S-50 $\mu \mathrm{m}, 12 \mathrm{~nm}$ ) (YMC Co., Ltd., Kyoto, Japan) were used for column chromatography. Semipreparative HPLC was performed using an ODS column (YMCODS-A, $250 \times 10 \mathrm{~mm}, 5 \mu \mathrm{m})$. CD spectra were measured on a Biologic MOS-450 spectra polarimeter (Biologic Science, Claix, France). ECD spectra were measured with a Chirascan circular dichroism spectrometer (Applied Photophysics). MTT and antimicrobial assays were analyzed using a microplate reader (BioTek Synergy H1, BioTek Instruments, Inc., Winooski, VT, USA).

\subsection{Fungal Material}

The fungal strain XWS03F09 was isolated from the sponge Phakellia fusca, which was collected from the Xisha Islands of China in 2012. It was identified as Pestalotiopsis heterocornis XWS03F09 by analysis of its ITS region of the rDNA as described, which has been deposited in the GenBank database (accession no. JN943628.1). A voucher specimen (No. XWS03F09) was deposited in the School of Pharmacy, Southwest Medical University, Luzhou, Sichuan, China.

\subsection{Fermentation, Extraction, and Isolation}

The fungal strain Pestalotiopsis heterocornis XWS03F09 was grown at $28^{\circ} \mathrm{C}$ without shaking for 36 days in $1000 \mathrm{~mL}$ conical flasks containing solid rice medium (each flask contained $200 \mathrm{~g}$ of rice, $6 \mathrm{~g}$ of artificial sea salt; $200 \mathrm{~mL}$ of distilled water, boiled in an autoclave for $20 \mathrm{~min}$ at $121^{\circ} \mathrm{C}$ ). The total of fermented rice cultures was extracted with EtOAc three times to afford $165 \mathrm{~g}$ of crude extract (Figure S64).

The extract was subjected to silica gel column chromatography eluting with a gradient $\mathrm{CH}_{2} \mathrm{Cl}_{2}-\mathrm{MeOH}$ (30:1-0:100) to give 9 fractions based on TLC properties. Fraction 3 was separated by silica gel column chromatography eluting with petroleum ether-EtOAc (6:1) to give seven subfractions (Frs. 3.1-3.7). Fr. 3.2 was subjected to Sephadex LH-20 chromatography $(\mathrm{MeOH})$ to afford three subfractions (Frs. 3.2.1-3.2.3). Frs. 3.2.2 was purified by semipreparative HPLC $\left(70 \% \mathrm{MeOH} / \mathrm{H}_{2} \mathrm{O}\right)$ to afford $\mathbf{1}(7.0 \mathrm{mg})$ and $2(3.0 \mathrm{mg})$. Fr. 3.3 was subjected to Sephadex LH-20 chromatography to produce four subfractions (Frs. 3.3.1-3.3.4). Fr. 3.3.2 was separated by ODS column chromatography eluting with $\mathrm{MeOH}-\mathrm{H}_{2} \mathrm{O}(60 \%)$ to yield $5(7.0 \mathrm{mg})$. Fr. 3.4 was subjected to a Sephadex LH-20 column $(\mathrm{MeOH})$ and purified by preparative TLC to give $9(4.0 \mathrm{mg})$. Fraction 4 was isolated by column chromatography on silica gel eluting with petroleum ether-EtOAc (4:1-0:1) to yield five subfractions (Frs. 4.1-4.5). Fr. 4.1 was separated by semipreparative HPLC (60\% $\left.\mathrm{MeOH} / \mathrm{H}_{2} \mathrm{O}\right)$ to produce $3(3.5 \mathrm{mg})$ and $4(8.0 \mathrm{mg})$. Fr. 4.2 was separated by a Sephadex LH-20 column eluting with $\mathrm{MeOH}$ to yield three subfractions (Frs. 4.2.1-4.2.3). Fr. 4.2.3 was separated by repeated column chromatography and further purification with semipreparative $\mathrm{HPLC}\left(60 \% \mathrm{MeOH} / \mathrm{H}_{2} \mathrm{O}\right)$ to give $10(2.0 \mathrm{mg}), \mathbf{1 1}(1.0 \mathrm{mg})$. Fr. 4.3 was subjected to silica gel column chromatography eluting with a $\mathrm{CH}_{2} \mathrm{Cl}_{2}$-Acetone to yield five subfractions (Frs. 4.3.1-4.3.5). Fr. 4.3.3 was purified by semipreparative HPLC $\left(55 \% \mathrm{MeOH} / \mathrm{H}_{2} \mathrm{O}\right)$ to afford $12(7.0 \mathrm{mg})$. Fraction 5 was subjected to silica gel column chromatography eluting with $\mathrm{CH}_{2} \mathrm{Cl}_{2}$-Acetone (3:1) to yield five subfractions (Frs. 5.1-5.5). Fr. 5.3 was separated over an ODS column eluting with a gradient of $\mathrm{MeOH}$ and $\mathrm{H}_{2} \mathrm{O}$ and further purified by semipreparative HPLC with $\mathrm{MeOH}-\mathrm{H}_{2} \mathrm{O}(40: 60)$ to afford $7(4.0 \mathrm{mg})$ and $8(4.0 \mathrm{mg})$. Fr. 5.3 was fractionated on Sephadex LH-20 (MeOH) to provide four subfractions (Fr. 5.3.1-5.3.4). 
Fr. 5.3.2 was repeatedly purified using semipreparative HPLC with $\mathrm{MeOH}-\mathrm{H}_{2} \mathrm{O}$ to give 6 (20.0 mg).

Heterocornol $Q(1)$ : white amorphous solid; $[\alpha]_{\mathrm{D}}^{25}-5.1(c$ 0.4, $\mathrm{MeOH}) ; \mathrm{UV}(\mathrm{MeOH})$ $\lambda_{\max }(\log \varepsilon) 280$ (2.64), 271 (2.66), 226 (3.33), 208 (3.74) nm; CD (MeOH) $\lambda_{\max }(\Delta \varepsilon) 206(-3.19)$, 235 (0.39), IR (film) $v_{\max } 3360,2916,1612,1550,1373,1290,1199,1105,1053,927, \mathrm{~cm}^{-1} ;{ }^{1} \mathrm{H}$ NMR and ${ }^{13} \mathrm{C}$ NMR data, see Table 1 ; HRESIMS $m / z 257.0783$ [M + Na $]^{+}$(calculated for $\left.\mathrm{C}_{13} \mathrm{H}_{14} \mathrm{NaO}_{4}, 257.0790\right)$.

Heterocornol $R(2)$ : white amorphous solid; $[\alpha]_{\mathrm{D}}^{25}+46.6$ (c 0.1, $\left.\mathrm{MeOH}\right)$; UV $(\mathrm{MeOH})$ $\lambda_{\max }(\log \varepsilon) 280$ (3.66), 271 (2.67), 223 (4.32), 212 (4.47) nm; CD (MeOH) $\lambda_{\max }(\Delta \varepsilon) 207$ (5.68), 236 (-1.57), IR (film) $v_{\max }$ 3340, 2916, 1612, 1506, 1377, 1290, 1197, 1161, 1080, 1051, 1014, $927 \mathrm{~cm}^{-1} ;{ }^{1} \mathrm{H}$ NMR and ${ }^{13} \mathrm{C}$ NMR data, see Table 1 ; HRESIMS at $m / z 233.0806$ [M - H] ${ }^{-}$ (calculated for $\mathrm{C}_{13} \mathrm{H}_{13} \mathrm{O}_{4}, 233.0814$ ).

Heterocornol S (3): white amorphous solid; $[\alpha]_{\mathrm{D}}^{25}-1.4(c 0.2, \mathrm{MeOH}) ; \mathrm{UV}(\mathrm{MeOH})$ $\lambda_{\max }(\log \varepsilon) 287$ (3.36), 206 (4.18) nm; CD (MeOH) $\lambda_{\max }(\Delta \varepsilon) 208(-1.41), 278(0.45), 300$ $(-0.12)$, IR (film) $v_{\max } 3331,3298,2972,2930,2852,1717,1636,1456,1373,1240,1076,1018$, $667 \mathrm{~cm}^{-1}$; ${ }^{1} \mathrm{H}$ NMR and ${ }^{13} \mathrm{C}$ NMR data, see Table 1 ; HRESIMS m/z 401.1955 [M + Na] ${ }^{+}$ (calculated for $\mathrm{C}_{21} \mathrm{H}_{30} \mathrm{NaO}_{6}, 401.1940$ ).

Heterocornol T (4): white amorphous solid; $[\alpha]_{\mathrm{D}}^{25}+1.9$ (c 0.2, $\left.\mathrm{MeOH}\right) ; \mathrm{UV}(\mathrm{MeOH})$ $\lambda_{\max }(\log \varepsilon) 287$ (3.43), $206(4.21) \mathrm{nm} ; \mathrm{CD}(\mathrm{MeOH}) \lambda_{\max }(\Delta \varepsilon) 208$ (2.25), 240 (-0.24), 279 (-0.50), 299 (0.96), IR (film) $v_{\max }$ 3323, 3244, 2968, 2862, 1717, 1647, 1603, 1456, 1373, 1240, $1188,1151,1081,1041,815 \mathrm{~cm}^{-1} ;{ }^{1} \mathrm{H}$ NMR and ${ }^{13} \mathrm{C}$ NMR data, see Table 1 ; HRESIMS $\mathrm{m} / \mathrm{z}$ 401.1937 [M+Na] $]^{+}$(calculated for $\mathrm{C}_{21} \mathrm{H}_{30} \mathrm{NaO}_{6}, 401.1940$ ).

Heterocornol U (5): white amorphous solid; $[\alpha]_{\mathrm{D}}^{25}-2.4$ (c 0.20, MeOH); UV $(\mathrm{MeOH})$ $\lambda_{\max }(\log \varepsilon) 276$ (3.58), 269 (3.59), $218(4.35) \mathrm{nm} ; \mathrm{CD}(300 \mu \mathrm{g} / \mathrm{mL}) ; \mathrm{CD}(\mathrm{MeOH}) \lambda_{\max }(\Delta \varepsilon) 200$ (-2.85), 250 (0.08), IR (film) $v_{\max }$ 3404, 3335, 2938, 1713, 1599, 1470, 1373, 1254, 1151, 1022, 1007, $835 \mathrm{~cm}^{-1} ;{ }^{1} \mathrm{H}$ NMR and ${ }^{13} \mathrm{C}$ NMR data, see Tables 2 and 3; HRESIMS $\mathrm{m} / z$ 289.1047 $[\mathrm{M}+\mathrm{Na}]^{+}$(calculated for $\mathrm{C}_{14} \mathrm{H}_{18} \mathrm{NaO}_{5}, 289.1052$ )

Heterocornol $V(6)$ : white amorphous solid; $[\alpha]_{\mathrm{D}}^{25}-2.5$ (c $\left.0.1, \mathrm{MeOH}\right) ; \mathrm{UV}(\mathrm{MeOH})$ $\lambda_{\max }(\log \varepsilon) 276$ (3.72), 269 (3.73), 220 (4.51) nm; IR (film) $v_{\max }$ 3414, 2972, 2934, 1732, 1653, 1602, 1498, 1456, 1373, 1240, $1028 \mathrm{~cm}^{-1} ;{ }^{1} \mathrm{H}$ NMR and ${ }^{13} \mathrm{C}$ NMR data, see Tables 2 and 3; HRESIMS $m / z 289.1046[\mathrm{M}+\mathrm{Na}]^{+}$(calculated for $\mathrm{C}_{14} \mathrm{H}_{18} \mathrm{NaO}_{5}, 289.1052$ ).

Heterocornols W (7): white amorphous solid; $[\alpha]_{\mathrm{D}}^{25}-10.0(c 0.2, \mathrm{MeOH}) ; \mathrm{UV}(\mathrm{MeOH})$ $\lambda_{\max }(\log \varepsilon) 273.8$ (3.62), 213 (4.40) nm; IR (film) $\nu_{\max } 3414,2940,2870,1732,1717,1640,1456$, 1373, 1149, $1024 \mathrm{~cm}^{-1} ;{ }^{1} \mathrm{H}$ NMR and ${ }^{13} \mathrm{C}$ NMR data, see Tables 2 and 3; HRESIMS $\mathrm{m} / z$ 415.1755 [M + Na] $]^{+}$(calculated for $\mathrm{C}_{21} \mathrm{H}_{28} \mathrm{NaO}_{7}, 415.1733$ ).

Heterocornol X (8): white amorphous solid; $[\alpha]_{\mathrm{D}}^{25}-14.6($ c 0.1, MeOH); UV $(\mathrm{MeOH})$ $\lambda_{\max }(\log \varepsilon) 272$ (3.78), 208 (4.60) nm; IR (film) $\nu_{\max } 3414,2941,2870,1732,1716,1650,1490$, 1485, 1373, 1240, $1026 \mathrm{~cm}^{-1} ;{ }^{1} \mathrm{H}$ NMR and ${ }^{13} \mathrm{C}$ NMR data, see Tables 2 and 3; HRESIMS $m / z 415.1745[\mathrm{M}+\mathrm{Na}]^{+}$(calculated for $\mathrm{C}_{21} \mathrm{H}_{28} \mathrm{NaO}_{7}, 415.1733$ ).

$\left(2 S, 2^{\prime} R, 3 R, 4 E, 8 E\right)-N-2^{\prime}$-Hydroxyhexadecanoyl-2-amino-9-methyl-4, 8-octadecadiene-yl acetate (9): amorphous powder; $[\alpha]_{\mathrm{D}}^{25}+13.0($ c $0.1 \mathrm{MeOH}) ;{ }^{1} \mathrm{H} \mathrm{NMR}$ and ${ }^{13} \mathrm{C} \mathrm{NMR}$ data, see Tables 2 and 3; HRESIMS m/z 608.5251 [M + H] $]^{+}$(calculated for $\mathrm{C}_{37} \mathrm{H}_{70} \mathrm{NO}_{5}, 608.5254$ ).

\subsection{ECD Calculations}

The calculations of new compounds were performed by using the TDDFT method as carried out using the Gaussian 09 program [30]. Conformational analysis was initially conducted by using the Spartan'14 software. Conformers with a Boltzmann distribution over $5 \%$ (the relative energy within $6 \mathrm{kcal} / \mathrm{mol}$ ) were chosen for ECD calculations at the B3LYP /6-311+G(d,p) level. The ECD spectra of different conformers were generated using the program SpecDis by applying a Gaussian band shape with a $0.30 \mathrm{eV}$ width, according to the Boltzmann-calculated contribution after UV correction. 


\subsection{Cell Culture and Cytotoxicity Assay}

The hela, A549, HCT-8, A2780, and RAW 264.7 cells were cultured in DMEM medium with $10 \% \mathrm{FBS}, 2 \mathrm{mM}$ glutamine, $100 \mathrm{U} / \mathrm{mL}$ of penicillin, and $100 \mu \mathrm{g} / \mathrm{mL}$ of streptomycin at $37^{\circ} \mathrm{C}$ under $5 \% \mathrm{CO}_{2}$ atmosphere. The cytotoxicities of $\mathbf{1 - 9}$ and $\mathbf{1 2}$ against five cell lines, including hela, A549, HCT-8, A2780, and RAW 264.7, were evaluated by the MTT method described in the literature [31].

\subsection{Antimicrobial Assay}

A micro broth dilution assay as previously reported [32] was used to evaluate the MICs of 1-9 and $\mathbf{1 2}$ against three bacteria (Staphylococcus aureus ATCC 25923, Bacillus subtilis ATCC 6633, Escherichia coli ATCC 25922), and one fungi (Candida albicans MYA-2867). The MIC was defined as the lowest concentration of the antimicrobial agent that completely inhibited visual growth of an organism. Ciprofloxacin and amphotericin B (Sigma Inc.) were used as positive controls against bacteria and fungi, respectively.

\subsection{Determination of Nitric Oxide Production}

The RAW 264.7 cells seeded at $1 \times 10^{6}$ cell/well in six-well plates. After $24 \mathrm{~h}$, the cells pretreated with compounds $7(0,3,11,33 \mu \mathrm{M}), 8(0,3,11,33 \mu \mathrm{M})$, and dexamethasone (DXM, $33 \mu \mathrm{M})$ for $2 \mathrm{~h}$, and then stimulated with LPS $(1 \mu \mathrm{g} / \mathrm{mL})$ for $24 \mathrm{~h}$. The supernatant was collected for detecting the NO production with the Griess method.

\subsection{Western Blot Analysis}

The RAW 264.7 cells were pretreated with compounds $7(0,3,11,33 \mu \mathrm{M}), 8(0,3,11$, $33 \mu \mathrm{M})$, and DXM $(33 \mu \mathrm{M})$ for $2 \mathrm{~h}$, and then stimulated with LPS $(1 \mu \mathrm{g} / \mathrm{mL})$ for $24 \mathrm{~h}$. Total protein was extracted via RIPA (Beyotime, Beijing, China) and the concentration measured by BCA protein assay kit (Beyotime, Beijing, China). The $(40 \mu \mathrm{g})$ protein was separated with 10\% SDS-PAGE and transferred onto PVDF membrane (Millipore, Billerca, MA, USA), which was blocked for $1 \mathrm{~h}$ with 5\% non-fat milk in TBS at room temperature. Then, the membrane was incubated with primary antibody overnight, then washed three times with TBST and incubated with horseradish peroxidase conjugated secondary antibody for $1 \mathrm{~h}$ at room temperature, washed three times with TBST and visualized by CEL (Millipore). GAPDH served as an internal control. Band pattern was analyzed with Fluor Chem FC3 system (ProteinSimple, San Francisco, CA, USA).

\subsection{Data Analysis}

The data were expressed as the mean \pm S.E. of at least three independent experiments. The statistical significance of the differences between the means was determined either using Student's t-test or one-way analysis of variance where appropriate. If the means were found to be significantly different, multiple pairwise comparisons were carried out by Tukey's post hoc test. The threshold value for acceptance of difference was $5 \%(p \leq 0.05)$.

\section{Conclusions}

Eight new polyketide derivatives, heterocornols Q-X (1-8), one new ceramide (9), and three known analogues (10-12) were isolated from the sponge-derived fungus Pestalotiopsis heterocornis XWS03F09. The structures and absolute configurations of the new compounds were elucidated by spectroscopic data and calculated by ECD analysis. Compound $\mathbf{1 2}$ displayed growth inhibition towards S. aureus, B. subtilis, and E. coli, with MIC values ranging from 25 to $100 \mu \mathrm{g} / \mathrm{mL}$. Heterocornols T and X (7 and 8) could inhibit the production of LPS-induced NO significantly, comparable to dexamethasone. The result showed that 7 and $\mathbf{8}$ might serve as potential leads for development of anti-inflammatory activity.

Supplementary Materials: The following are available online at https:/ / www.mdpi.com/article/10 .3390 / md19110585/s1, Figures S1-S64: ${ }^{1} \mathrm{H},{ }^{13} \mathrm{C}$, HSQC, HMBC, COSY, NOESY, IR, and HRESIMS spectra of the new compounds 1-9. 
Author Contributions: H.L. performed the extraction, isolation and identification, and prepared manuscript. X.L. (Xiuping Lin) contributed to the collection, isolation, and identification the fungal strain. X.B., H.N. and D.Z. contributed to this work by bioassay experiments. X.L. (Xiaowei Luo) and J.S. accomplished the ECD calculation. B.Y. performed the elucidation of structures and revised the manuscript. All authors have read and agreed to the published version of the manuscript.

Funding: This work was funded by the Open Project of Sichuan Industrial Institute of Antibiotics, Chengdu University (ARRLKF20-04), Applied Basic Research Fund of Luzhou municipal government-Southwest Medical University (2018LZXNYD-ZK13), Project of Southwest Medical University (2017-ZRQN-093), Special Funds for Promoting Economic Development (Marine Economic Development) of Guangdong Province (No. [2020]039), Guangdong Local Innovation Team Program (2019BT02Y262), and Guangdong Basic and Applied Basic Research Foundation (2019B151502042).

Institutional Review Board Statement: Not applicable.

Data Availability Statement: The data presented in this study are available in the main text and the Supplementary Materials of this article.

Conflicts of Interest: The authors declare no conflict of interest.

\section{References}

1. Yoon, V.; Nodwell, J.R. Activating secondary metabolism with stress and chemicals. J. Ind. Microbiol. Biotechnol. 2014, 41, 415-424. [CrossRef]

2. Bode, H.B.; Bethe, B.; Höfs, R.; Zeeck, A. Big effects from small changes: Possible ways to explore nature's chemical diversity. ChemBioChem 2002, 3, 619-627. [CrossRef]

3. Wang, W.J.; Li, D.Y.; Li, Y.C.; Hua, H.M.; Ma, E.L.; Li, Z.L. Caryophyllene sesquiterpenes from the marine-derived fungus Ascotricha sp. ZJ-M-5 by the one strain-many compounds strategy. J. Nat. Prod. 2014, 77, 1367-1371. [CrossRef]

4. Rateb, M.E.; Houssen, W.E.; Harrison, W.T.A.; Deng, H.; Okoro, C.K.; Asenjo, J.A.; Andrews, B.A.; Bull, A.T.; Goodfellow, M.; Ebel, R.; et al. Diverse metabolic profiles of a streptomyces strain isolated from a hyper-arid environment. J. Nat. Prod. 2011, 74, 1965-1971. [CrossRef] [PubMed]

5. Paranagama, P.A.; Wijeratne, E.M.K.; Gunatilaka, A.A.L. Uncovering biosynthetic potential of plant-associated fungi: Effect of culture conditions on metabolite production by paraphaeosphaeria quadriseptata and chaetomium chiversii (1). J. Nat. Prod. 2007, 70, 1939-1945. [CrossRef]

6. Wang, X.R.; Filho, J.G.S.; Hoover, A.R.; King, J.B.; Ellis, T.K.; Powell, D.R.; Cichewicz, R.H. Chemical epigenetics alters the secondary metabolite composition of guttate excreted by an atlantic-forest-soil-derived Penicillium citreonigrum. J. Nat. Prod. 2010, 73, 942-948. [CrossRef] [PubMed]

7. Sun, K.L.; Zhu, G.L.; Hao, J.J.; Wang, Y.; Zhu, W.M. Chemical-epigenetic method to enhance the chemodiversity of the marine algicolous fungus, Aspergillus terreus OUCMDZ-2739. Tetrahedron 2018, 74, 83-87. [CrossRef]

8. Akone, S.H.; Mandi, A.; Kurtan, T.; Hartmann, R.; Lin, W.H.; Daletos, G.; Proksch, P. Inducing secondary metabolite production by the endophytic fungus Chaetomium sp. through fungal-bacterial co-culture and epigenetic modification. Tetrahedron 2016, 72 , 6340-6347. [CrossRef]

9. Han, J.Y.; Zhang, J.Y.; Song, Z.J.; Zhu, G.L.; Liu, M.M.; Dai, H.Q.; Hsiang, T.; Liu, X.T.; Zhang, L.X.; Quinn, R.J.; et al. Genomebased mining of new antimicrobial meroterpenoids from the phytopathogenic fungus Bipolaris sorokiniana strain 11134. Appl. Microbiol. Biotechnol. 2020, 104, 3835-3846. [CrossRef]

10. Challis, G.L. Genome mining for novel natural product discovery. J. Med. Chem. 2008, 51, 2618-2628. [CrossRef]

11. Ziemert, N.; Alanjary, M.; Weber, T. The evolution of genome mining in microbes-A review. Nat. Prod. Rep. 2016, 33, 988-1005. [CrossRef]

12. Helfrich, E.J.N.; Reite, S.; Piel, J. Recent advances in genome-based polyketide discovery. Curr. Opin. Biotechnol. 2014, 29 , 107-115. [CrossRef]

13. Nett, M.; Ikeda, H.; Moore, B.S. Genomic basis for natural product biosynthetic diversity in the actinomycetes. Nat. Prod. Rep. 2009, 26, 1362-1384. [CrossRef]

14. Lei, H.; Lin, X.P.; Han, L.; Ma, J.; Dong, K.L.; Wang, X.B.; Mu, Y.; Liu, Y.H.; Huang, X.S. Polyketide derivatives from a marine-sponge-associated fungus Pestalotiopsis heterocornis. Phytochemistry 2017, 142, 51-59. [CrossRef]

15. Lei, H.; Lei, J.; Zhou, X.F.; Hu, M.; Niu, H.; Song, C.; Chen, S.W.; Liu, Y.H.; Zhang, D. Cytotoxic polyketides from the marine sponge-derived fungus pestalotiopsis heterocornis XWS03F09. Molecules 2019, 24, 2655. [CrossRef] [PubMed]

16. Lei, H.; Lin, X.P.; Han, L.; Ma, J.; Ma, Q.J.; Zhong, J.L.; Liu, Y.H.; Sun, T.M.; Wang, J.H.; Huang, X.S. New metabolites and bioactive chlorinated benzophenone derivatives produced by a marine-derived fungus Pestalotiopsis heterocornis. Mar. Drugs 2017, 15, 69. [CrossRef] [PubMed]

17. Cueto, M.; Jensen, P.R.; Kauffman, C.; Fenical, W.; Lobkovsky, E.; Clardy, J. Pestalone, a new antibiotic produced by a marine fungus in response to bacterial challenge. J. Nat. Prod. 2001, 64, 1444-1446. [CrossRef] [PubMed] 
18. Li, E.; Jiang, L.H.; Guo, L.D.; Zhang, H.; Che, Y.S. Pestalachlorides A-C, antifungal metabolites from the plant endophytic fungus Pestalotiopsis adusta. Bioorg. Med. Chem. 2008, 16, 7894-7899. [CrossRef]

19. Wang, J.F.; Liang, R.; Liao, S.R.; Yang, B.; Tu, Z.C.; Lin, X.P.; Wang, B.G.; Liu, Y.H. Vaccinols J-S, ten new salicyloid derivatives from the marine mangrove-derived endophytic fungus Pestalotiopsis vaccinii. Fitoterapia 2017, 120, 164-170. [CrossRef]

20. Höller, U.; Gloer, J.B.; Wicklow, D.T. Biologically active polyketide metabolites from an undetermined fungicolous hyphomycete resembling Cladosporium. J. Nat. Prod. 2002, 65, 876-882. [CrossRef]

21. Xing, Q.; Gan, L.S.; Mou, X.F.; Wang, W.; Wang, C.Y.; Wei, M.Y.; Shao, C.L. Isolation, resolution and biological evaluation of pestalachlorides $\mathrm{E}$ and $\mathrm{F}$ containing both point and axial chirality. RSC Adv. 2016, 6, 22653-22658. [CrossRef]

22. Pescitelli, G.; Bruhn, T. Good computational practice in the assignment of absolute configurations by TDDFT calculations of ECD spectra. Chirality 2016, 28, 466-474. [CrossRef]

23. Kurtan, T.; Antus, S.; Pescitelli, G. Comprehensive Chiroptical Spectroscopy; Berova, N., Polavarapu, P.L., Nakanishi, K., Woody, R.W., Eds.; Wiley: Hoboken, NJ, USA, 2012; Volume 2, pp. 73-114.

24. Chen, X.W.; Li, C.W.; Cui, C.B.; Hua, W.; Zhu, T.J.; Gu, Q.Q. Nine new and five known polyketides derived from a deep sea-sourced Aspergillus sp. 16-02-1. Mar. Drugs 2014, 12, 3116-3137. [CrossRef] [PubMed]

25. Xia, M.W.; Cui, C.B.; Li, C.W.; Wu, C.J. Three new and eleven known unusual C25 steroids: Activated production of silent metabolites in a marine-derived fungus by chemical mutagenesis strategy using diethyl sulphate. Mar. Drugs 2014, 12, 1545-1568. [CrossRef]

26. Yaoita, Y.; Kohata, R.; Kakuda, R.; Machida, K.; Kikuchi, M. Ceramide constituents from five mushrooms. Chem. Pharm. Bull. 2002, 50, 681-684. [CrossRef] [PubMed]

27. García, M.O.; Rodriguez, A.D. Palominin, a novel furanosesterterpene from a Caribbean sponge Iricinia sp. Tetrahedron 1990, 46, 1119-1124. [CrossRef]

28. Yaoita, Y.; Satoh, Y.; Kikuchi, M. A new ceramide from Ramaria botrytis (Pers.) Ricken. J. Nat. Med. 2007, 61, 205-207. [CrossRef]

29. Kwon, H.C.; Kim, K.R.; Zee, S.D.; Cho, S.Y.; Lee, K.R. A new indolinepeptide from Paecilomyces sp. J300. Arch. Pharm. Res. 2004, 27, 604-609. [CrossRef]

30. Frisch, M.J.; Trucks, G.W.; Schlegel, H.B.; Scuseria, G.E.; Robb, M.A.; Cheeseman, J.R. Gaussian 09, Revision D.01; Gaussian, Inc.: Wallingford, CT, USA, 2013.

31. Jin, Y.; Aobulikasimu, N.; Zhang, Z.G.; Liu, C.B.; Cao, B.X.; Lin, B.; Guan, P.P.; Mu, Y.; Jiang, Y.; Han, L.; et al. Amycolasporins and dibenzoyls from lichen-associated Amycolatopsis hippodromi and their antibacterial and antiinflammatory activities. J. Nat. Prod. 2020, 83, 3545-3553. [CrossRef]

32. Ding, N.; Jiang, Y.; Han, L.; Chen, X.; Ma, J.; Qu, X.; Mu, Y.; Liu, J.; Li, L.; Jiang, C.; et al. Bafilomycins and odoriferous sesquiterpenoids from Streptomyces albolongus isolated from Elephas maximus feces. J. Nat. Prod. 2016, 79, 799-805. [CrossRef] 